\title{
Elemental Silver Nanoparticles: Biosynthesis and Bio Applications
}

\author{
Oleg V. Mikhailov * and Ekaterina O. Mikhailova \\ Analytical Chemistry, Certification and Quality Management, Kazan National Research Technological University, \\ K. Marx Street 68, 420015 Kazan, Russia; katyushka.glukhova@gmail.com \\ * Correspondence: olegmkhlv@gmail.com
}

Received: 31 August 2019; Accepted: 24 September 2019; Published: 27 September 2019

\begin{abstract}
The data on the specifics of synthesis of elemental silver nanoparticles (Ag-NP) having various geometric shapes (pseudo spherical, prismatic, cubic, trigonal-pyramidal, etc.), obtained by using various biological methods, and their use in biology and medicine have been systematized and generalized. The review covers mainly publications published in the current 21st century. Bibliography: 262 references.
\end{abstract}

Keywords: Ag-NP; geometric shape; green synthesis; plants; microorganisms; biological applications

\section{Introduction}

Elemental silver nanoparticles (Ag-NP) have been known in anthropogenic activities since very ancient times (although nobody had an idea about their existence). For example, detailed study of one of the late Roman Empire cultural masterpieces, namely the Lycurgus Cup (IV century ad), has shown that the glass inserts in its bronze frame owe their specific coloring (red in reflected light and gray-green in transmitted) to the presence of nanoparticles that are 70\% elemental silver [1]. Even earlier (II century ad), so-called "Holy Water", which is not exposed to infection by microorganisms and spoilage for many months and years, was known; moreover, it has a very detrimental effect on a wide variety of pathogenic microorganisms [2]. At the end of the 19th century, the phenomenon "oligodynamia" - the silver bactericidal effect on the cells of microorganisms by $\mathrm{Ag}^{+}$ions-was found by the Swiss botanist K. Nägeli [3]. However, more detailed study about the antibacterial activity of "Holy Water", carried out in the second half of the 20th century, showed that it is connected with both the presence of $\mathrm{Ag}^{+}$ions and the presence of Ag-NP [4]. Herewith, among elemental metal nanoparticles, namely elemental silver has the strongest bactericidal effect $[5,6]$, which is a direct consequence of the optimal ratio of their surface areas and volumes. Now the bactericidal, bacteriostatic, antiviral, antifungal and antiseptic effect of silver ions and Ag-NP suspensions has been shown on more than 500 pathogenic microorganisms, yeast fungi and viruses. Moreover, their antibacterial and antiviral activity is even more pronounced than the effect of penicillin, biomycin and other "classic" antibiotics $[7,8]$. Low probability of certain mutations with the result of resistance to Ag-NP becomes extremely important in the struggle of microbiologists with an ever-growing assortment of pathogenic bacteria and viruses that are resistant to traditional antibiotics. This important circumstance, relatively low toxicity and allergenicity of Ag-NP, and its good tolerance by patients, has contributed to the increased interest in Ag-NP in many countries of the world and the creation of various medical preparations based on anti-inflammatory, antiseptic and bactericidal action.

The study of the mechanism of antibacterial activity of Ag-NP showed that this property is due to morphological and structural changes in bacterial cells [4]. A priori, it is obvious that the degree of this effect should depend significantly on the size and shape of Ag-NP. On the other hand, in many studies of recent decades, the size, morphology, stability, and both chemical and physical 
properties of elemental metal nanoparticles, including silver, were very dependent on the parameters of the processes by which they are formed. These parameters are directly related to the specifics of the given processes, reactions of the metal ions interaction with reducing agents, and sorption processes of stabilizing agents on nanoparticles, which prevent their aggregation with each other [9]. In general, control of the shape, size and distribution of the resulting Ag-NP is achieved by varying the methods of their synthesis, reducing the influence of fluctuations, and stabilizing factors affecting the above parameters of nanoparticles [10-14]. By varying the conditions for the synthesis of Ag-NP, characteristics such as color, melting point, magnetic properties, redox potential of $\mathrm{Ag}(\mathrm{I}) / \mathrm{Ag}$, etc. can be changed and controlled in a fairly wide range [15-20]. Comprehensive coverage of Ag-NP problems was presented in reviews $[19,20]$. However, the main focus was on the synthesis of Ag-NP using various physicochemical methods. Another synthetic method, in which some objects of biological origin are used to obtain elemental silver nanoparticles, has become increasingly popular. This approach has certain advantages in comparison with traditional physicochemical methods, and the possibilities of its implementation for the production of Ag-NP are not only not exhausted, but even not completely identified. The review is dedicated to this issue.

\section{General Principles of Biosynthesis of Elemental Silver Nanoparticles (Ag-NP)}

The basis of all chemical and physicochemical methods for the synthesis of Ag-NP is the idea of a specific increase in the area of their faces in the presence of certain chemical reagents. Biological methods base on similar idea, but biological objects (microorganisms, products of their vital activity, extracts of plants, etc.) are used for the formation of Ag-NP. As a rule, Ag-NP is obtained as a result of the reduction of certain $\mathrm{Ag}(\mathrm{I})$ compounds (usually $\mathrm{AgNO}_{3}$ ), under the influence of various reducing inorganic agents (f.e., hydrazine $\mathrm{N}_{2} \mathrm{H}_{4}$, sodium tetrahydridoborate(III) $\mathrm{Na}\left[\mathrm{BH}_{4}\right]$ ), as well as organic (f.e, ethyleneglycol, ascorbic acid). The process of reducing Ag(I) compounds to elemental silver according to the $\mathrm{Ag}(\mathrm{I}) \rightarrow \mathrm{Ag}$ scheme can occur in a variety of reaction media; at the same time, specific chemical reagents (most often polyvinylpyrrolidone) are used to stabilize the resulting nanoparticles (to prevent their aggregation). The formation of Ag-NP, according to data [19,21,22], begins with the incipience of a decahedral "embryo" formed by five tetrahedral clusters that have common faces. Since the dihedral angle in the tetrahedron is $\sim 70.5^{\circ}$, namely the decahedron, consisting of five tetrahedrons, is that structural element from which the most thermodynamically stable forms of Ag-NP. It should be noted that the dihedral angle in the tetrahedron indicated above is slightly smaller than the angle in the above decahedron $\left(72^{\circ}\right)$; therefore, tetrahedrons cannot be perfectly packed into a decahedron without gaps (which lead to the formation of structural defects) [19]. Such a scheme displays only a simplest variant of the formation of Ag-NP, which leads to the formation of elemental silver nanocrystals in the form of nanorods or "nanowires". In reality, this process often turns out to be significantly more complex and interesting, and as a result, other geometric forms-tabular prisms, cubes, octahedrons, pyramids etc., can be realized $[19,20]$. As it was shown in various studies, the shape and size of the resulting Ag-NP depend on many experimental parameters. These can be the temperature, the concentration of the compound $\mathrm{Ag}(\mathrm{I})$, the $\mathrm{pH}$ of the solution, the molar ratio between stabilizing agent and the precursor containing $\mathrm{Ag}(\mathrm{I})\left(\mathrm{AgNO}_{3}, \mathrm{AgCl}\right.$, et al.), the degree of chemical interaction of the molecules of the stabilizing agent with various crystallographic planes of elemental silver [22]. The nature of the reducing agent of $\mathrm{Ag}(\mathrm{I})$ compounds (citric acid, $L$-ascorbic acid, $\mathrm{NaBH}_{4}$ et al.) and the method used to produce Ag-NP (chemical, physical or biological) play an extremely important role, too. Using particles with a specific morphology (for example, polyhedral or twin) as a "primer", it is possible under certain synthesis conditions to purposefully control the final "architecture" of Ag-NP [19,23,24].

The chemical and physicochemical methods used to produce Ag-NP, are usually quite expensive; in addition, toxic chemical compounds are often used in them. Biological methods are practically devoid of these disadvantages. Of course, they are also not ideal: it should be noted that the reproducibility of the Ag-NP synthesis results is worse than in the case of physicochemical methods. Despite this, 
the number of works about Ag-NP biosynthesis has a pronounced tendency to annual growth. In modern literature, Ag-NP biosynthesis is often called "green synthesis".

The three key types of biological objects used for this purpose-extracts of various plants, various microorganisms, and animal products, can be distinguished in the literature about Ag-NP biosynthesis. It should be noted that many works devoted to this problem, were published either in biological journals or in medical journals. Most of these publications were devoted not only to Ag-NP biosynthesis, but also the possibility of using silver nanoparticles as antibacterial agents. This aspect of Ag-NP characterization of, of course, is very important and interesting, and it will also be analyzed in this review along with a discussion of their synthesis.

Now there are a lot of papers in the field of the Ag-NP "green synthesis". In this regard, a difficult question arises as to how to systematize the available material on the given problem. The "catchiest" characteristic of nanoparticles and Ag-NP, undoubtedly, is their shape, because it largely determines their properties (including the properties of the materials in composition of which are these nanoparticles). For this reason, available literary material was systematized by the types of biological objects used for the synthesis of Ag-NP and by the shape of elemental silver nanoparticles formed in this process.

Getting a little ahead in the course of the presentation, we would like to note that such geometric shapes of Ag-NP, which were obtained using chemical and physicochemical methods, apparently, could also be obtained using biological methods, although not all of these possible shapes were received experimentally.

\section{Synthesis of Ag-NP Using Extracts of Various Plants}

Plant extracts obtained from leaves, stems, roots, etc. as the result of exposure to various liquid solvents-extractants. Water, ethanol, dimethyl ether, plant oil, etc. can act as extractants. Plant extracts are complex in composition, containing various chemical compounds arising in the process of plant life, and transferring into solution during extraction. In the process of the synthesis of Ag-NP according to the general scheme $\mathrm{Ag}(\mathrm{I}) \rightarrow \mathrm{Ag}$, the chemical compounds contained in the extract can fulfill three functions: (1) act as a reducing agent of silver(I) compounds to elemental silver, (2) act as an agent that has a specific influence on the formation of a certain shape and size of Ag-NP due to inhibition of the growth of certain faces of the nanocrystals of these nanoparticles and (3) to act as a stabilizer formed during the synthesis of Ag-NP, preventing their self-association and (or) aggregation with each other. Due to the fact that the composition of the original plant material depends significantly on the type of a particular plant, the qualitative and quantitative composition of the resulting extracts can vary widely. Moreover, even for the same plant species, it does not remain constant and in some cases depends significantly on the conditions of its growth. Therefore, it is likely that the technology of synthesis of Ag-NP using extracts of the same plant, but in laboratories located in different regions of our planet, can lead to very different final results (we mean the shape and size elemental silver nanoparticles). Thus, the reproducibility of Ag-NP biosynthesis results will not be too good a priori. It should be noted that despite the very large number of works devoted to the Ag-NP biosynthesis using plant extracts, among them there are not even two such works in which extracts from the same plant species were used, but grown in different geographical, climatic and soil conditions.

An extremely large number of publications have been devoted to the "green synthesis" of Ag-NP using biological objects of this type [25-108]. In all of them only $\mathrm{AgNO}_{3}$ was used as a precursor containing Ag(I) for the Ag-NP synthesis. Particles having a spherical and/or oval (ellipsoidal) shape were identified in most of the experiments; shapes differed from those, were observed in the experiment much rarely [91-108]. In this connection, it should be noted that, spherical and oval shapes are conglomerates of smaller "embryonic" particles of elemental silver, which are complex combinations of "starting" geometric forms indicated in [19]. To some extent, this can be confirmed by scanning electron microscope (SEM) images of spherical Ag-NPs at high resolution [24], shown in Figure 1. Given this 
fact, it would be better to call such Ag-NP pseudospherical nanocrystals. Despite this, we will continue to use the generally accepted term to refer to these objects (i.e., spherical Ag-NPs).
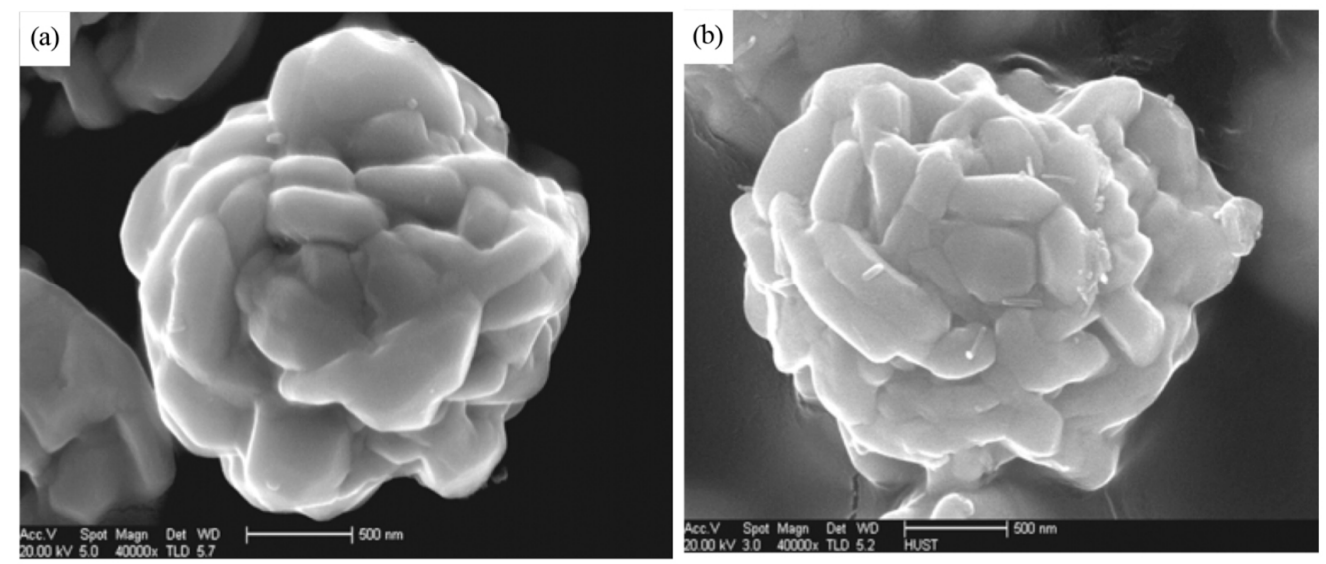

Figure 1. Typical scanning electron microscope (SEM) images of pseudo-spherical elemental silver nanoparticles (Ag-NP) at high resolution (a) none modifier; (b) at the presence of $1.0 \mathrm{~g} / \mathrm{L}$ N-methyl 2-pyrrolidone [24].

Among the earliest works of the 21st century devoted to the production of silver nanoparticles using plant extracts is the publication of Shankar, Ahmad and Sastry [25], in which Geranium Pelargonium graveolens leaf extract was used to synthesize Ag-NP. The spherical Ag-NP particles were obtained with the size varied in the range of $16-40 \mathrm{~nm}$. Later, a group of researchers [26] received spherical silver nanoparticles using Emblica officinalis (amla, Indian Gooseberry) fruit extract with sizes from 15 to $25 \mathrm{~nm}$, and, also, elemental gold nanoparticles with slightly smaller (10-20 nm) sizes. Similar results were achieved by Chandran et al [27], in which Aloe Vera leaf extract was used to synthesize Ag-NP. The spherical Ag-NP particles, the size of which varied in the range $(15.2+4.2) \mathrm{nm}$, were shown. The authors of [28] obtained spherical silver nanoparticles using Capsicum annuиm $L$. extract with sizes from 50 to $70 \mathrm{~nm}$. The results the given work allow to affirm that silver nanoparticles synthesized from such a method, show antibacterial activity against $E$. coli. Cruz et al. [29] obtained a spherical Ag-NP with an average diameter of $15-30 \mathrm{~nm}$, using leaf extract of Lippia citriodora (Lemon Verbena). Close-sized Ag-NPs were received in the work [30] using the leaf extract of Acalypha indica. Spherical Ag-NPs were also shown by the authors of [31] using an extract of the dried leaves of the plant Tribulus terrestris. The sizes of the Ag-NPs synthesized by them were in the range of (18-47) $\mathrm{nm}$. The Ag-NPs obtained retained high stability (i.e., did not aggregate with each other) even after three months of storage at $37^{\circ} \mathrm{C}$. Along with this, Ag-NP received in [31] showed a pronounced antibacterial effect on a number of clinically isolated microorganisms, which have now developed resistance to many drugs. Ag-NPs of similar shape from the leaf extract of Mimusops elengi, were described by Prakash with co-authors in [32], but these silver nanoparticles had diameters in the range of 55 to $83 \mathrm{~nm}$. In [33], spherical Ag-NPs 25-59 nm in size were synthesized using the Chrysanthemum indicum flower extract. In all, in the last 10 years a variety of plants were used to synthesize spherical Ag-NPs [34-93]; the information about these plants, as well as the shape and size obtained with their use of elemental silver nanoparticles are presented in Table 1 at the end of this section of the paper. As can be seen from the data in the given table, during the synthesis of Ag-NP leaf extracts were usually preferred, although in some cases other parts of the corresponding plants-flowers, roots, fruits, etc. were used for this purpose, as it took place in particular in $[33,41,43,67,75,79,86,87]$. Scanning electron microscopy (SEM) of Ag-NP, obtained in the one of these works [86], is presented on Figure 2. A few exceptions are publications [42,57,65], in which seaweed Ulva lactucain (Figure 3) [42], Sargassum wightii [57] and Sargassum vulgare [65] were used as an accompanying agent for "green synthesis" of Ag-NP. It is significant that, the synthesis of silver nanoparticles in these works was carried out, as a rule, in a neutral medium. The Ag-NP size was very diverse among using plant extracts (Table 1). At the 
same time, however, the question of the amount effect of plant extract used in the synthesis on the size of Ag-NP is rarely considered. One of the few such works is [58], which examines Olax scandens.

Table 1. Sizes and shapes of Ag-NP obtained by "green synthesis" using plant extracts.

\begin{tabular}{|c|c|c|c|c|c|}
\hline Plant & $\begin{array}{c}\text { Part Used } \\
\text { for Synthesis }\end{array}$ & Shape (form) & $\begin{array}{c}\text { Size of } \\
\text { Ag-NP (nm) }\end{array}$ & $\begin{array}{c}\text { Max of Absorption } \\
\text { of Ag-NP } \\
\text { in Visible Spectrum (nm) }\end{array}$ & Ref. \\
\hline $\begin{array}{l}\text { Pelargonium graveolens } \\
\text { (Geranium) }\end{array}$ & Leaves & Spherical & $16-40$ & 440 & [25] \\
\hline $\begin{array}{l}\text { Emblica Officinalis } \\
\text { (Amla, Indian Gooseberry) }\end{array}$ & Fruits & Spherical & $15-25$ & $400-420$ & [26] \\
\hline Aloe Vera & Leaves & Spherical & $15.2 \pm 4.2$ & 410 & [27] \\
\hline Capsicum annuиm & Leaves & Spherical & $50-70$ & 428 & [28] \\
\hline $\begin{array}{l}\text { Lippia citriodora } \\
\text { (Lemon Verbena) }\end{array}$ & Leaves & Spherical & $15-30$ & $430-440$ & [29] \\
\hline Acalypha indica & Leaves & Spherical & $20-30$ & 425 & [30] \\
\hline Tribulus terrestris & $\begin{array}{l}\text { Exsiccated } \\
\text { leaves }\end{array}$ & Spherical & $18-47$ & 450 & [31] \\
\hline Mimusops elengi & Leaves & Spherical & $55-83$ & 440 & [32] \\
\hline Chrysanthemum indicum & Flowers & Spherical & $25-59$ & 430 & [33] \\
\hline Cinnamomum canphora & Leaves & Spherical & $55-80$ & 440 & [34] \\
\hline Eclipta & Leaves & Spherical & $2-6$ & 419 & [35] \\
\hline Ocimum sanctum (Tulsi) & Leaves & Spherical & $4-30$ & 413 & [36] \\
\hline Cassia auriculata & Leaves & Spherical & $1-100$ & 450 & [37] \\
\hline $\begin{array}{l}\text { Euphorbia hirta } \\
\text { Nerium indicum }\end{array}$ & Leaves & Spherical & $29-31$ & 380,460 & [38] \\
\hline Rosa Chinensis & Leaves & Spherical & $25-60$ & No $\lambda \max$ data & [39] \\
\hline Tribulus terrestris & Fruit & Spherical & $16-28$ & 435 & [40] \\
\hline Dioscorea bulbifera & Tuber & $\begin{array}{l}\text { Triangular, } \\
\text { Nanorod }\end{array}$ & $8-20$ & 455 & [41] \\
\hline Ulva lactucain & Whole plant & Spherical & 76 & 434 & [42] \\
\hline Trianthema decandra & Root & Spherical & $36-74$ & Absent & [43] \\
\hline Cissus quadrangularis & Whole plant & Spherical & $50-100$ & 450 & [44] \\
\hline Iresine herbstii & Leaves & Spherical & $44-64$ & 420 & [45] \\
\hline Ananas comosus & Fruits & Spherical & $\sim 12$ & 430 & [46] \\
\hline Boswellia serrata & Gum & Spherical & $7.5 \pm 3.8$ & 420 & [47] \\
\hline Hibiscus cannabinus & Leaves & Spherical & $9-10$ & 446 & [48] \\
\hline Piper pedicellatum & Leaves & Spherical & $2-30$ & 440 & [49] \\
\hline Tithonia diversifolia & Leaves & Spherical & $\sim 25$ & Absent & [50] \\
\hline Ficus panda & Leaves & Spherical & $12-36$ & 421 & [51] \\
\hline Citrullus colocynthis & $\begin{array}{l}\text { Leaves } \\
\text { Root } \\
\text { Seeds } \\
\end{array}$ & $\begin{array}{l}\text { Spherical } \\
\text { Spherical } \\
\text { Spherical }\end{array}$ & $\begin{array}{c}13.37 \\
7.39 \\
16.57 \\
\end{array}$ & No. $\lambda$ max data & [52] \\
\hline Alternanthera sessilis & Leaves & Spherical & $30-50$ & 420 & [53] \\
\hline Podophyllum hexandrum & Leaves & Spherical & $\sim 14$ & 430 & [54] \\
\hline Cocos nucifera & Inflorescence & Spherical & $\sim 22$ & 420 & [55] \\
\hline Olea europaea (Olive) & Leaves & Spherical & $20-25$ & $441-456$ & [56] \\
\hline Sargassum wightii (algae) & Whole & Spherical & $5-22$ & 439 & [57] \\
\hline
\end{tabular}


Table 1. Cont.

\begin{tabular}{|c|c|c|c|c|c|}
\hline Plant & $\begin{array}{c}\text { Part Used } \\
\text { for Synthesis }\end{array}$ & Shape (form) & $\begin{array}{c}\text { Size of } \\
\text { Ag-NP (nm) }\end{array}$ & $\begin{array}{c}\text { Max of Absorption } \\
\text { of Ag-NP } \\
\text { in Visible Spectrum (nm) }\end{array}$ & Ref. \\
\hline Olax scandens & Leaves & Spherical & $30-60$ & $410-430$ & [58] \\
\hline Piper longum & Fruits & Spherical & $\sim 46$ & 465 & [59] \\
\hline Delonix elata & Leaves & Spherical & $35-45$ & 432 & [60] \\
\hline Adansonia digitata & Fruits & Spherical & $3-57$ & 434 & [61] \\
\hline Emblica officinalis & Fruits & Spherical & $15-20$ & 425 & [62] \\
\hline Rheum emodi & Root & Spherical & $10-40$ & 425 & [63] \\
\hline Allium sativum & Whole plant & Spherical & $100-800$ & No. $\lambda$ max data & [64] \\
\hline Sargassum vulgare (algae) & Whole plant & Spherical & $\sim 10$ & No. $\lambda$ max data & [65] \\
\hline Erythrina indica lam & Root & Spherical & $20-118$ & 438 & [66] \\
\hline Plumeria alba & Flowers & Spherical & 36.2 & 455 & [67] \\
\hline Cymodocea serrulata & Whole plant & Spherical & $17-29$ & 430 & [68] \\
\hline Skimmia laureola & Leaves & Spherical & & 460 & [69] \\
\hline Butea monosperma & Leaves & Spherical & $20-80$ & $440-475$ & [70] \\
\hline Capparis decidua & Leaves & Spherical & $1.5-25$ & 452 & [71] \\
\hline Azadirachta indica & Leaves & Spherical & $\sim 34$ & $436-446$ & [72] \\
\hline $\begin{array}{l}\text { Syzygium cumini } \\
\text { Azadirachta indica }\end{array}$ & $\begin{array}{l}\text { Flowers } \\
\text { Leaves }\end{array}$ & $\begin{array}{l}\text { Spherical } \\
\text { Spherical }\end{array}$ & $\begin{array}{l}<40 \\
<40\end{array}$ & $400-450$ & [73] \\
\hline Capparis spinosa & Leaves & Spherical & $10-40$ & 420 & [74] \\
\hline Cola nitida & Pods & Spherical & $12-80$ & 431 & [75] \\
\hline Artemisia marschalliana & Aerial part & Spherical & $5-50$ & 430 & [76] \\
\hline Ziziphus oenoplia & Leaves & Spherical & 10 & 436 & [77] \\
\hline Croton bonplandianum Baill. & Leaves & Spherical & 32 & 425 & [78] \\
\hline Dimocarpus longan & Peel & Spherical & $8-22$ & No. $\lambda$ max data & [79] \\
\hline Rubus glaucus & Leaves & Spherical & $12-50$ & $440-445$ & [80] \\
\hline Raphanus sativus & Leaves & Spherical & $4-30$ & 426 & [81] \\
\hline Melia azedarach & Leaves & Spherical & $34-48$ & 482 & [82] \\
\hline Calliandra haematocephala & Leaves & Spherical & $13.5-91.3$ & 414 & [83] \\
\hline Crocus sativus & Leaves & Spherical & $12-20$ & 450 & [84] \\
\hline Costus afer & Leaves & Spherical & $\sim 20$ & $405-411$ & [85] \\
\hline Punica granatum & Peel & Spherical & $20-40$ & Absent & [86] \\
\hline Cleome viscosa & Fruits & Spherical & $20-50$ & $410-430$ & [87] \\
\hline Anthemis atropatana & Aerial part & Spherical & $10-80$ & 430 & [88] \\
\hline Citrullus colocynthis & Callus & Spherical & $\sim 31$ & No. $\lambda$ max data & [89] \\
\hline Datura stramonium & Leaves & Spherical & $15-20$ & 444 & [90] \\
\hline Morinda citrifolia & Root & Spherical & $30-55$ & 413 & [91] \\
\hline Ficus talboti & Leaves & Spherical & $10-14$ & 438 & [92] \\
\hline Potentilla fulgens & Root & Spherical & $10-15$ & 410 & [93] \\
\hline $\begin{array}{l}\text { Syzygium cumini } \\
\text { Citrus sinensis } \\
\text { Solanum tricobatum } \\
\text { Centella asiatica }\end{array}$ & $\begin{array}{l}\text { Leaves } \\
\text { powder }\end{array}$ & Triangular & $\begin{array}{l}53 \\
41 \\
52 \\
42\end{array}$ & 420 & [94] \\
\hline Rheum palmatum & Root & Hexagonal & $121 \pm 2$ & 440 & [95] \\
\hline
\end{tabular}


Table 1. Cont.

\begin{tabular}{|c|c|c|c|c|c|}
\hline Plant & $\begin{array}{c}\text { Part Used } \\
\text { for Synthesis }\end{array}$ & Shape (form) & $\begin{array}{c}\text { Size of } \\
\text { Ag-NP (nm) }\end{array}$ & $\begin{array}{c}\text { Max of Absorption } \\
\text { of Ag-NP } \\
\text { in Visible Spectrum (nm) }\end{array}$ & Ref. \\
\hline Alysicarpus monilifer & Leaves & $\begin{array}{l}\text { Hexagonal, } \\
\text { Spherical }\end{array}$ & $5-45$ & 422 & [96] \\
\hline Melia azedarach & Leaves & Cubic & 78 & 436 & [97] \\
\hline Eucalyptus macrocarpa & Leaves & Cubic & $10-50$ & 430 & [98] \\
\hline $\begin{array}{l}\text { Cucurbita maxima } \\
\text { Moringa oleifera } \\
\text { Acorus calamus }\end{array}$ & $\begin{array}{l}\text { Petals } \\
\text { Leaves } \\
\text { Rhizome }\end{array}$ & Cubic & $30-70$ & Absent & [99] \\
\hline $\begin{array}{l}\text { Ocimum tenuiflorum } \\
\text { Solanum tricobatum } \\
\text { Syzygium cumini } \\
\text { Centella asiatica } \\
\text { Citrus sinensis }\end{array}$ & Leaves & Prismatic & $\begin{array}{c}28 \\
22.3 \\
26.5 \\
28.4 \\
65\end{array}$ & $\begin{array}{l}420 \\
420 \\
420 \\
415 \\
415\end{array}$ & [100] \\
\hline Achillea biebersteinii & Flowers & $\begin{array}{l}\text { Pentagonal } \\
\text { Spherical }\end{array}$ & $10-40$ & 450 & [101] \\
\hline Solanum trilobatum & Fruits & Polygonal & $41-42$ & 420 & [102] \\
\hline Musa paradisiaca (banana) & Peels & Irregular & $\sim 24$ & 433 & [103] \\
\hline Annona squamosa & Leaves & Irregular & $\sim 300$ & 420 & {$[104]$} \\
\hline Artemisia nilagirica & Leaves & Irregular & $\leq 30$ & 463 & [105] \\
\hline Tinospora cordifolia & Leaves & $\begin{array}{l}\text { Irregular } \\
\text { Spherical }\end{array}$ & $\sim 30$ & 430 & [106] \\
\hline $\begin{array}{l}\text { Leucas aspera } \\
\text { Hyptis suaveolens }\end{array}$ & $\begin{array}{l}\text { Leaves } \\
\text { Leaves }\end{array}$ & $\begin{array}{l}\text { Irregular } \\
\text { Polygonal }\end{array}$ & $\begin{array}{l}7-22 \\
5-25\end{array}$ & $\begin{array}{l}401 \\
408\end{array}$ & [107] \\
\hline Órchis máscula & Tuber & "Flower-like" & $\begin{array}{c}<100 \\
\text { (width) } \\
\sim 500 \\
\text { (length) }\end{array}$ & 444 & [108] \\
\hline
\end{tabular}

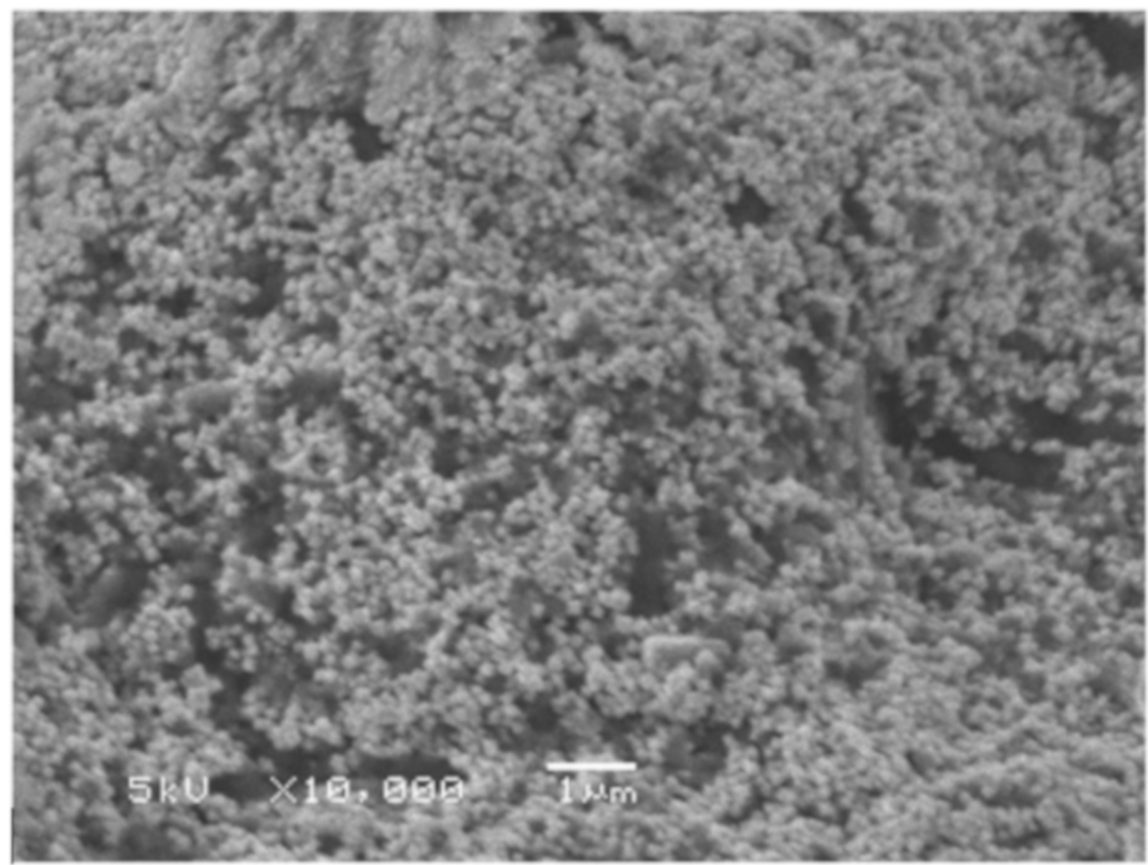

Figure 2. Scanning electron microscope (SEM) images of Ag-NP obtained using aqueous peel extract of Punica granatum [86]. 


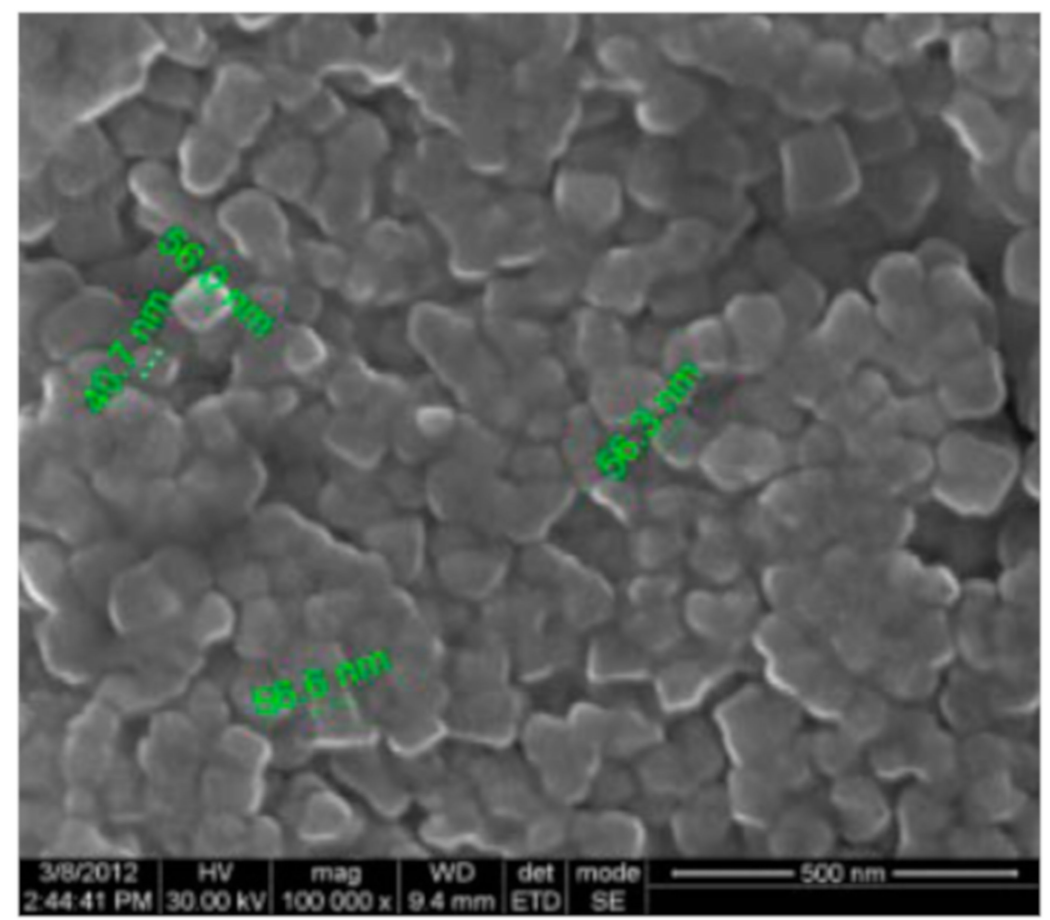

Figure 3. SEM images of Ag-NP obtained using aqueous extract of marine seaweed Ulva lactucain [42].

Leaf extract was used in the synthesis process. According to the data of this work, the average size of Ag-NP is 30-60 nm; however, the situation is rather more difficult: when the volume ratio of the $\mathrm{AgNO}_{3}$ solutions used by them and the extract was 1:1, the size of Ag-NP was in the range of 20-110 $\mathrm{nm}$ at ratios of 1:2.67 and 1:3.33-from 10 to $85 \mathrm{~nm}$, with a ratio of 1:5-from 10 to $90 \mathrm{~nm}$ [58]. Presumably the same phenomenon would have occurred with the use of other plant extracts described in [25-108], but this point remained out of the field of view of their authors.

Ag-NPs from plant extracts with a shape different from spherical, were noted in a relatively small number of published works. In [34,41,94], the synthesis of trigonal Ag NPs having the shape of triangular plates was described. Hexagonal and spherical shapes of Ag-NPs having a size of $(121 \pm 2) \mathrm{nm}$ were described by Arokiyaraj et al, using water extracts of Rheum palmatum roots [95]. The synthesized nanoparticles showed very high antibacterial activity against some pathogenic microorganisms: Staphylococcus and Pseudomonas. Using a leaf extract of Alysicarpus monilifer, the authors of [96] could obtain monodisperse Ag-NPs of predominantly spherical shape with a small hexagonal distortion with sizes in the range (5-45) $\mathrm{nm}$ and average particle size $(15 \pm 2) \mathrm{nm}$. At the same time, along with spherical Ag-NPs, they discovered the formation of a certain amount of Ag-NPs having a trigonal tabular and hexagonal tabular form. A small amount of the mixed phase containing hexagonal Ag-NP was also noted in an earlier article [28].

Ag-NP with a cubic form from plant extracts was also known in [97-99]. In the first of these publications, elemental silver nanoparticles were prepared using a leaf extract of Melia azedarach. The cubic Ag-NPs synthesized in [97] had a size of about $80 \mathrm{~nm}$ (Figure 4). The authors of the publication [98] reported "green synthesis" of Ag-NP, spherical and cubic shape, using leaf extracts from Eucalyptus macrocarpa and carried out at room temperature. During their experiment, it was also found that in the process of synthesis, this extract acts both as a reducing and stabilizing agent. Herewith, according to transmission electron microscope (TEM) data, the size of spherical Ag-NPs was in the range (10-100) nm, while the size of cubic Ag-NPs was in the range (10-50) nm. In this connection, we should note that the three-dimensional field-emission SEM (FESEM) image obtained several hours after the completion of the experiment showed that namely cubic but not spherical nanoparticles with sizes from 50 to $100 \mathrm{~nm}$ became the dominant shapes [98]. In [99], three different plants were used to 
receive such cubic nanoparticles, namely Cucurbita maxima, Moringa oleifera, and Acorus calamus. In this regard, it is interesting that various parts of these plants (peels, leaves and rhizome, respectively) were used to prepare plant extracts. The sizes of silver nanoparticles obtained in [99] varied in the range of $30-70 \mathrm{~nm}$.

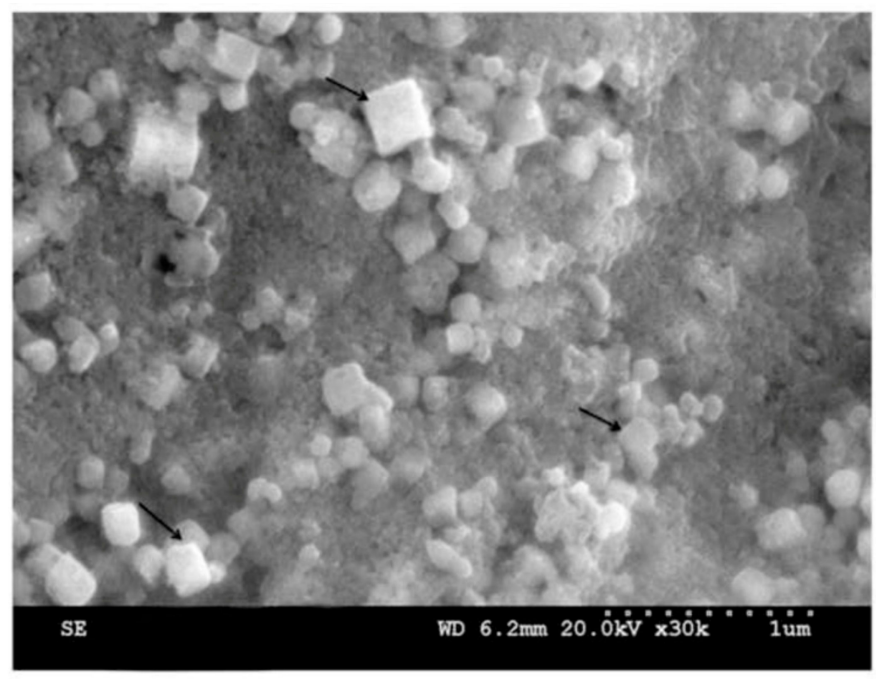

Figure 4. SEM images of Ag-NP obtained using aqueous leaf extract of Melia azedarach [97].

The authors of [100] observed the formation of prismatic Ag-NPs with sizes of 22-65 nm using leaf extracts of Ocimum tenuiflorum, Solanum tricobatum, Syzygium cumini, Centella asiatica, and Citrus sinensis for "green synthesis". For these Ag-NPs, a strong tendency toward coalescence was found, which is most represented in the case of Centella asiatica and least in the case of Syzygium cumini (Figure 5). Baharara et al. in the publication [101] described the synthesis of elemental silver nanoparticles, some of which had a pentagonal-tabular shape; in the absorption spectra of these Ag-NPs, a distinct maximum was observed at $450 \mathrm{~nm}$ [101]. Along with this, in a number of works on biosynthesis using plant extracts [102-107], other (mainly irregular) forms of Ag-NP were noted. So, in [105] by using leaf extract Artemisia nilagirica, silver nanoparticles shown in Figure 6 were synthesized. As can be seen, they are shapeless conglomerates and blocks resembling a pile of stones.

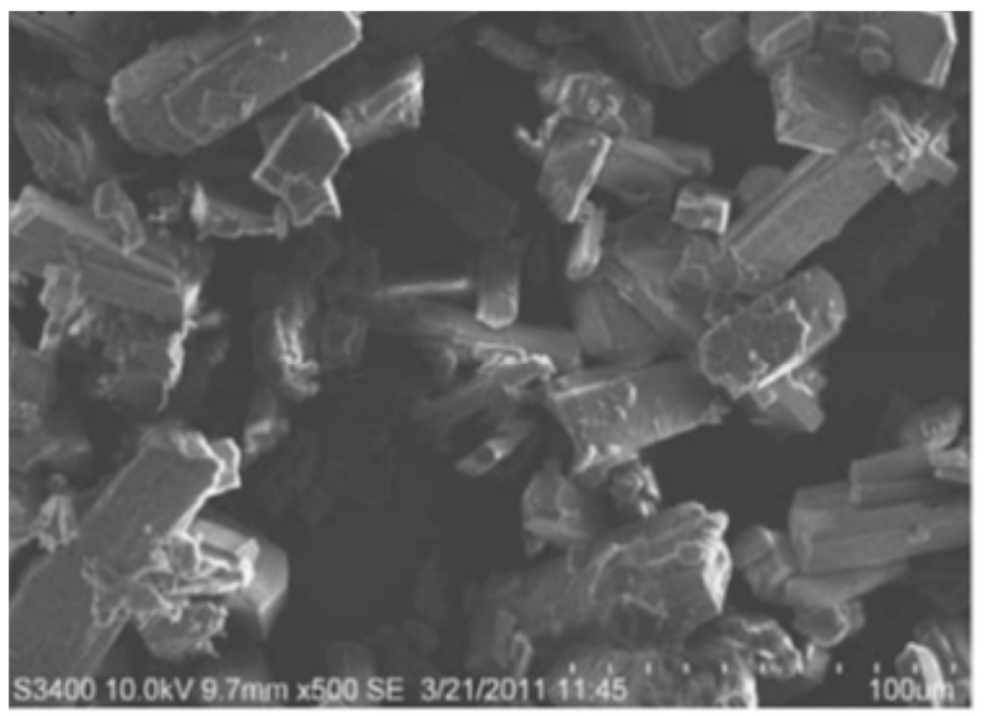

Figure 5. SEM images of Ag-NP obtained using aqueous leaf extract of Syzygium cumini [100]. 


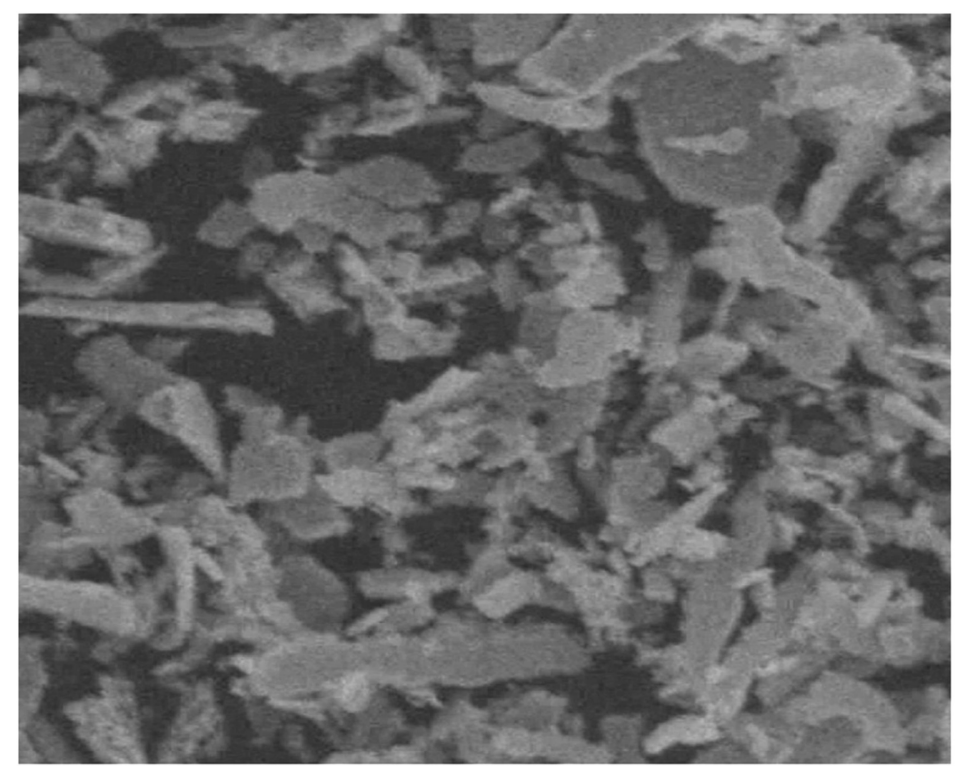

Figure 6. SEM images of Ag-NP obtained using aqueous leaf extract of Artemisia nilagirica [105].

From the extract of the leaves of Tinospora cordifolia [106] Ag-NP particles were obtained with an external form that resembles a highly distorted sphere, and with the use of extracts of Leucas aspera and leaves of Hyptis suaveolens particles, some of which had a distorted spherical shape, and other polygonal shape were shown [107].

The completely unusual "flower-like" form of Ag-NP was observed by Pourjavadi and Soleyman in [108]. In their study, with the remarkable name "Novel silver nano-wedges for killing microorganisms", a peculiar photochemical surface "green synthesis" was first applied to produce Ag-NP using the "Salep" (tuber extract of Orchis mascula). In the framework of such a synthesis, the reduction of $\mathrm{Ag}(\mathrm{I})$ to $\mathrm{Ag}-\mathrm{NP}$, in addition to the extract itself, was facilitated by sunlight (ultraviolet (UV) radiation). "Salep" also served as an effective capping biomaterial, providing the formation of "flower-like" self-organizing structures in the form of unique silver "nano-wedges". In addition, there was an aggregation of such structures, which resulted in the formation of Ag-NPs with the above unusual shape.

As can be seen from the data presented in Table 1, in most cases for Ag-NP synthesized using plant extracts, in the visible region of the spectrum, either a single absorption band with a maximum in the range of 400-460 nm or a "wing" band with a maximum in the Ultra-Violet region (UV) region were detected. Accordingly, their colloidal solutions are usually colored in orange, red or red-brown. However, any correlation between the sizes, as well as the shape of the nanoparticles and the position of this maximum in the ultraviolet-visible (UV-Vis) absorption spectra, as can be seen from experimental data presented in the Table 1, was not observed.

Review articles [109-113] were also devoted to the discussion of recent results on Ag-NP biosynthesis using plant extracts, in which references to a number of other, earlier works devoted to the "green synthesis" of silver nanoparticles using extracts of various plants can be found. A possible mechanism of the plant extracts' influence on the process of formation of Ag-NP has been considered in detail in recently published reviews $[113,114]$.

\section{Synthesis of Ag-NP Using Various Microorganisms}

The use of microorganisms (bacteria, microscopic fungi, etc.) for the synthesis of Ag-NP according to the general scheme $\mathrm{Ag}(\mathrm{I}) \rightarrow \mathrm{Ag}$ is based on the idea that they produce specific chemicals during their life, each of which can a priori perform the same functions (1-3), which were described in the previous section. In addition, these microorganisms are able to affect a certain influence on the size and shape of the elemental silver nanoparticles formed by themselves (i.e., outside of the connection 
with the nature of those products that are formed in the process of their development). In particular, in the final period of the formation of Ag-NP, when these nanoparticles will have reached relatively large sizes, microorganisms can overlap, with some fragments of their bodies, individual faces of already formed elemental silver nanocrystals, preventing their further growth. Thus, the action of microorganisms on the process under consideration is more multifactorial than the impact of plant extracts. However, in this variant of Ag-NP biosynthesis, the reproducibility of the results should be higher, because modern biotechnologies make it possible to purposefully control both the growth of microorganisms and the various substances produced by them.

The specificity of Ag-NP biosynthesis using various microorganisms was studied in the works [115-186]. In most of these publications, various bacteria were used as biological objects [115,116,122-125,127,128,130,132-136,138,140,141,143,144,146,147,150,151,153-156,158,161,163166,169,171-180,183-186]; rare such synthesis was carried out with the participation of various microscopic fungi [117-121,126,129,131,137,139,142,145,148,149,152,157,162,167,168,170,181,182]. It should be noted, as well as in the case of using plant extracts, the formation of pseudospherical Ag-NP most often took place [115-166]; other forms of silver nanoparticles, although noted in the experiment, were much rarer $[115,116,132,133,167-186]$. Data on the size and shape of Ag-NP obtained using various microorganisms are presented in Table 2.

One of the earliest works devoted to the biosynthesis of Ag-NP using microorganisms are the publications [115-118], where, along with spherical Ag-NP, nanoparticles with a different shape, namely, triangular and hexagonal, were described. After that, a lot of works on this topic appeared. The most popular microorganisms in the "green synthesis" of elemental silver nanoparticles are bacteria of the genus Bacillus $[122,123,130,132,133,140,143,154,159,169,179,180,183]$. So, the authors of [122], using Bacillus licheniformis, obtained pseudospherical Ag-NP with an average size of about $40 \mathrm{~nm}$, in the visible spectrum of which there was only a "wing" of the absorption band with a maximum in the UV region. The same kind of microorganisms was also used by Kalimuthu with co-authors [123], who, under somewhat different experimental conditions, showed pseudospherical Ag-NP with an average size of about $50 \mathrm{~nm}$, in the visible spectrum of which there was a band with a peak at $440 \mathrm{~nm}$. Saravanan et al. [159] synthesized Ag-NP having a size range of 41-68 nm with a spherical shape using B. brevis (NCIM 2533). Similar results were received using B. megaterium (NCIM 2326) for the synthesis of Ag-NP in another work of this author [169]. Overall, in most cases, only pseudospherical nanoparticles were the final products of biosynthesis using microorganisms. However, in some of the works, the researchers also recorded the formation of silver nanoparticles with other external shapes (Table 2). For example, using B. subtilis and B. amyloliquefaciens, the authors [132] and [133] respectively were able to observe the formation of triangular and hexagonal silver nanoparticles, along with spherical Ag-NP, and triangular, hexagonal and cubic shapes were described in [180]. The sizes of Ag-NP obtained in this case ranged from $2 \mathrm{~nm}$ in [180] to $99 \mathrm{~nm}$ in [169] (Table 2). It should be noted in this connection that triangular and hexagonal Ag-NP, using not these bacteria themselves (in this case, B. licheniformis), but the isolated enzyme from them, $\alpha$-amylase, was received by Mishra and Sardar [183]; the silver nanoparticles obtained had a size from 22 to $44 \mathrm{~nm}$. Bacteria of other genera were used for the biosynthesis of Ag-NP as a whole much rare, although in general their assortment is quite large (Table 2). Most often pseudo-spherical Ag-NP with very diverse sizes, very significantly depending on the nature of the microorganism, were shown. Examples of Ag-NP images with such an external shape received using bacteria are shown in Figure 7. It should be noted that any correlation (at least in qualitative terms) between the genus of bacteria and the parameters of those nanoparticles of elemental silver (size and shape of Ag-NP), which are formed with the active participation of these microorganisms, has not yet been detected. 
Table 2. Sizes and shapes of Ag-NP received by "green synthesis" by using various microorganisms.

\begin{tabular}{|c|c|c|c|c|}
\hline $\begin{array}{l}\text { Microorganism } \\
\text { (Type) }\end{array}$ & Shape (form) & $\begin{array}{c}\text { Size of } \\
\text { Ag-NP (nm) }\end{array}$ & $\begin{array}{c}\text { Max of } \\
\text { Absorption } \\
\text { of Ag-NP } \\
\text { in Visible Spectrum (nm) }\end{array}$ & Ref. \\
\hline Pseudomonas stutzeri (bacteria) & $\begin{array}{l}\text { Spherical } \\
\text { Triangular } \\
\text { Hexagonal }\end{array}$ & $70-200$ & 400 & [115] \\
\hline Pseudomonas stutzeri (bacteria) & $\begin{array}{l}\text { Spherical } \\
\text { Triangular } \\
\text { Hexagonal }\end{array}$ & $70-200$ & 400 & [116] \\
\hline MKY3 strain (bacteria) & $\begin{array}{l}\text { Spherical } \\
\text { Hexagonal }\end{array}$ & $\sim 26$ & 420 & [117] \\
\hline Fusarium oxysporum (fungus) & Spherical & $5-15$ & 413 & [118] \\
\hline Fusarium oxysporum (fungus) & Spherical & $20-50$ & 420 & [119] \\
\hline Aspergillus flavus (fungus) & Spherical & $\sim 9$ & 420 & [120] \\
\hline Fusarium acuminatum (fungus) & Spherical & $5-40$ & 420 & [121] \\
\hline Bacillus licheniformis (bacteria) & Spherical & $\sim 40$ & Absent & [122] \\
\hline Bacillus licheniformis (bacteria) & Spherical & $\sim 50$ & 440 & [123] \\
\hline Escherichia coli (bacteria) & Spherical & $\sim 50$ & 420 & [124] \\
\hline Klebsiella pneumonia (bacteria) & Spherical & $1-6$ & 420 & [125] \\
\hline Aspergillus niger (fungus) & Spherical & $3-30$ & 430 & [126] \\
\hline Brevibacterium casei (bacteria) & Spherical & $10-50$ & 420 & [127] \\
\hline Pseudomonas aeruginosa (bacteria) & Spherical & $\sim 13$ & 430 & [128] \\
\hline Rhizopus stolonifer (fungus) & Spherical & $3-20$ & Absent & [129] \\
\hline $\begin{array}{l}\text { Pseudomonas antarctica (bacteria) } \\
\text { Pseudomonas proteolytica (bacteria) } \\
\text { Pseudomonas meridian (bacteria) } \\
\text { Arthrobacter kerguelensis(bacteria) } \\
\text { Arthrobacter gangotriensis (bacteria) } \\
\text { Bacillus indicus (bacteria) } \\
\text { Bacillus cecembensis (bacteria) }\end{array}$ & Spherical & $6-13$ & $400-430$ & [130] \\
\hline Penicillium purpurogenum (fungus) & Spherical & $8-10$ & $390-420$ & [131] \\
\hline Bacillus subtilis (bacteria) & $\begin{array}{l}\text { Spherical } \\
\text { Triangular } \\
\text { Hexagonal }\end{array}$ & $45-70$ & 440 & [132] \\
\hline Bacillus amyloliquefaciens (bacteria) & $\begin{array}{l}\text { Spherical } \\
\text { Triangular }\end{array}$ & $\sim 15$ & $420-425$ & [133] \\
\hline Streptomyces sp. (bacteria) & Spherical & $21-48$ & 441 & [134] \\
\hline Streptomyces albogriseolus (bacteria) & Spherical & $16.25 \pm 1.6$ & 409 & [135] \\
\hline Salmonella typhirium (bacteria) & $\begin{array}{l}\text { Spherical } \\
\text { Ellipsoidal }\end{array}$ & $87 \pm 30$ & 427 & [136] \\
\hline Pencillium sp. (fungus) & Spherical & 25 & 425 & [137] \\
\hline Acinetobacter calcoaceticus (bacteria) & Spherical & $8-60$ & $420-440$ & [138] \\
\hline Aspergillus fumigatus (fungus) & Spherical & $20-140$ & 420 & [139] \\
\hline Bacillus subtilis (bacteria) & Spherical & No data & 420 & [140] \\
\hline Streptomyces sp. (bacteria) & Spherical & $50-86$ & 420 & [141] \\
\hline
\end{tabular}


Table 2. Cont.

\begin{tabular}{|c|c|c|c|c|}
\hline $\begin{array}{l}\text { Microorganism } \\
\text { (Type) }\end{array}$ & Shape (form) & $\begin{array}{c}\text { Size of } \\
\text { Ag-NP (nm) }\end{array}$ & $\begin{array}{c}\text { Max of } \\
\text { Absorption } \\
\text { of Ag-NP } \\
\text { in Visible Spectrum (nm) }\end{array}$ & Ref. \\
\hline Penicillium sp. (fungus) & Spherical & $25-30$ & 420 & [142] \\
\hline Bacillus sp. (bacteria) & Spherical & $42-94$ & 450 & [143] \\
\hline Actinomycetes (bacteria) & Spherical & $10-20$ & 415 & [144] \\
\hline Penicillium glabrum (fungus) & Spherical & $26-32$ & 420 & [145] \\
\hline Streptomyces sp. (bacteria) & Spherical & $50-76$ & 420 & [146] \\
\hline Ochrobactrum sp. (bacteria) & Spherical & $38-85$ & 450 & [147] \\
\hline Fusarium oxysporum (fungus) & Spherical & $15-40$ & 420 & [148] \\
\hline Penicillium atramentosum (fungus) & Spherical & $5-25$ & 420 & [149] \\
\hline Variovorax guangxiensis (bacteria) & Spherical & $10-40$ & 418 & [150] \\
\hline Sporosarcina koreensis (bacteria) & Spherical & $10-30$ & 424 & [151] \\
\hline Penicillium brevicompactum (fungus) & Spherical & $30-50$ & 420 & [152] \\
\hline Pseudomonas deceptionensis (bacteria) & Spherical & $10-30$ & 428 & [153] \\
\hline Bacillus methylotrophicus (bacteria) & Spherical & $10-30$ & 416 & [154] \\
\hline Streptomyces rochei (bacteria) & $\begin{array}{l}\text { Almost ideally } \\
\text { spherical }\end{array}$ & $22-85$ & 410 & [155] \\
\hline Streptomyces atrovirens (bacteria) & Spherical & $58 \pm 2$ & 418 & [156] \\
\hline Rhizopus stolonifer (fungus) & Spherical & $3-50$ & 420 & [157] \\
\hline Aeromonas sp. (bacteria) & Spherical & $8-16$ & 400 & [158] \\
\hline Bacillus brevis (bacteria) & Spherical & $41-68$ & 420 & [159] \\
\hline Phenerochaete chrysosporium (bacteria) & Spherical & $34-90$ & 430 & [160] \\
\hline Streptacidiphilus durhamensis (bacteria) & Spherical & $8-48$ & 430 & [161] \\
\hline Penicillium italicum (fungus) & Spherical & $14.5-23.3$ & 423 & [162] \\
\hline Streptomyces xinghaiensis (bacteria) & Spherical & $5-20$ & 420 & [163] \\
\hline Enterobacter cloacae (bacteria) & Spherical & $7-25$ & 440 & [164] \\
\hline Streptomyces olivaceus (bacteria) & Spherical & $\sim 12.3$ & 450 & [165] \\
\hline Paracoccus sp. (bacteria) & $\begin{array}{l}\text { Spherical } \\
\text { Ellipsoidal }\end{array}$ & $2-5$ & 416 & [166] \\
\hline Aspergillus fumigates (fungus) & Irregular & $5-25$ & 420 & [167] \\
\hline Aspergillus clavatus (fungus) & Irregular & $550-650$ & 420 & [168] \\
\hline Bacillus megaterium (bacteria) & Irregular & $80-99$ & Absent & [169] \\
\hline Aspergillus flavus (fungus) & Irregular & $17 \pm 5.9$ & 421 & [170] \\
\hline Pseudomonas aeruginosa (bacteria) & Irregular & $2-20$ & 425 & [171] \\
\hline Idiomarina sp (bacteria) & Irregular & 26 & 450 & [172] \\
\hline Staphylococcus aureus (bacteria) & Irregular & $28-50$ & $\begin{array}{l}420-430 \\
550-570\end{array}$ & [173] \\
\hline Streptomyces sp. (bacteria) & Irregular & 68 & 423 & [174] \\
\hline Enterococcus sp. (bacteria) & Irregular & $30-100$ & Absent & [175] \\
\hline Streptomyces sp. (bacteria) & Irregular & $70-100$ & 400 & [176] \\
\hline
\end{tabular}


Table 2. Cont.

\begin{tabular}{|c|c|c|c|c|}
\hline $\begin{array}{l}\text { Microorganism } \\
\text { (Type) }\end{array}$ & Shape (form) & $\begin{array}{c}\text { Size of } \\
\operatorname{Ag}-\mathrm{NP}(\mathrm{nm})\end{array}$ & $\begin{array}{c}\text { Max of } \\
\text { Absorption } \\
\text { of Ag-NP } \\
\text { in Visible Spectrum (nm) }\end{array}$ & Ref. \\
\hline Acinetobacter baumannii (bacteria) & Irregular & $37-168$ & Absent & [177] \\
\hline Pseudomonas sp. (bacteria) & Irregular & $10-40$ & 412 & [178] \\
\hline Bacillus flexus (bacteria) & Triangular & $12-65$ & 420 & [179] \\
\hline Bacillus stratosphericus (bacteria) & $\begin{array}{l}\text { Triangular } \\
\text { Hexagonal } \\
\text { Cubic }\end{array}$ & $2-20$ & 405 & [180] \\
\hline Fusarium semitectum (fungus) & $\begin{array}{l}\text { Hexagonal } \\
\text { Spherical }\end{array}$ & $10-60$ & 420 & [181] \\
\hline Aspergillus clavatus (fungus) & $\begin{array}{l}\text { Hexagonal } \\
\text { Spherical }\end{array}$ & $10-25$ & 415 & [182] \\
\hline Bacillus licheniformis (bacteria) & $\begin{array}{l}\text { Hexagonal } \\
\text { Triangular }\end{array}$ & $22-44$ & 422 & [183] \\
\hline Streptomyces viridodiastaticus (bacteria) & Polygonal & $15-45$ & 400 & [184] \\
\hline $\begin{array}{l}\text { Arthrospira maxima (cyanobacteria) } \\
\text { Arthrospira platensis (cyanobacteria) } \\
\text { Hapalosiphon fontinalis (cyanobacteria) } \\
\text { Spirulina sp. (cyanobacteria) } \\
\text { Cylindrospermum stagnale } \\
\text { (cyanobacteria) } \\
\text { Spirulina sp. (cyanobacteria) } \\
\text { Phormidium sp. (cyanobacteria) } \\
\text { Spirulina sp. (cyanobacteria) } \\
\text { Calothrix brevissema (cyanobacteria) }\end{array}$ & $\begin{array}{c}\text { Triangular } \\
\text { Triangular } \\
\text { Triangular } \\
\text { Pentagonal } \\
\text { Pentagonal } \\
\text { Hexagonal } \\
\text { Cubic } \\
\text { Cubic } \\
\text { Cubic }\end{array}$ & $\begin{array}{c}61 \\
46 \\
50 \\
51 \\
38-40 \\
47 \\
48 \\
49 \\
42\end{array}$ & $\begin{array}{l}465 \\
445 \\
450 \\
450 \\
440 \\
446 \\
446 \\
450 \\
443\end{array}$ & [185] \\
\hline Hargavaea indica (bacteria) & $\begin{array}{l}\text { Pentagonal } \\
\text { Spherical } \\
\text { Icosahedral } \\
\text { Hexagonal } \\
\text { Triangular } \\
\text { Icosahedral } \\
\text { Truncated } \\
\text { triangle }\end{array}$ & $30-100$ & 460 & [186] \\
\hline
\end{tabular}

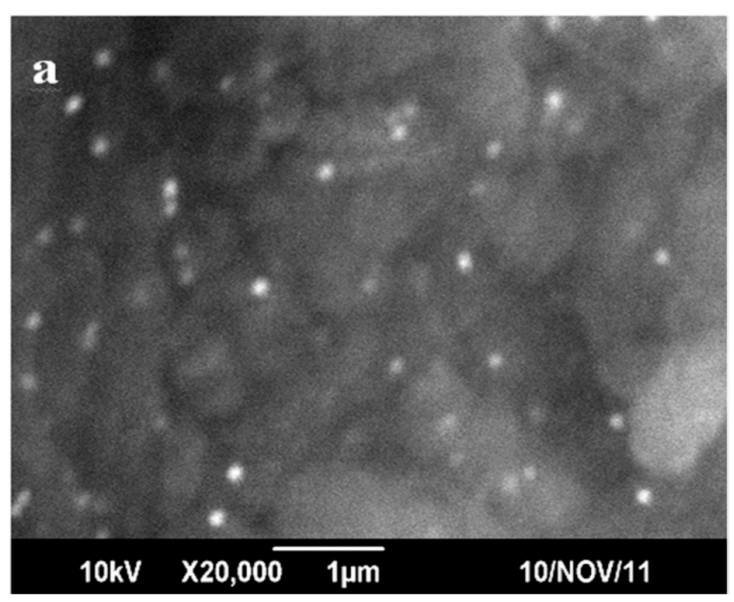

(a)

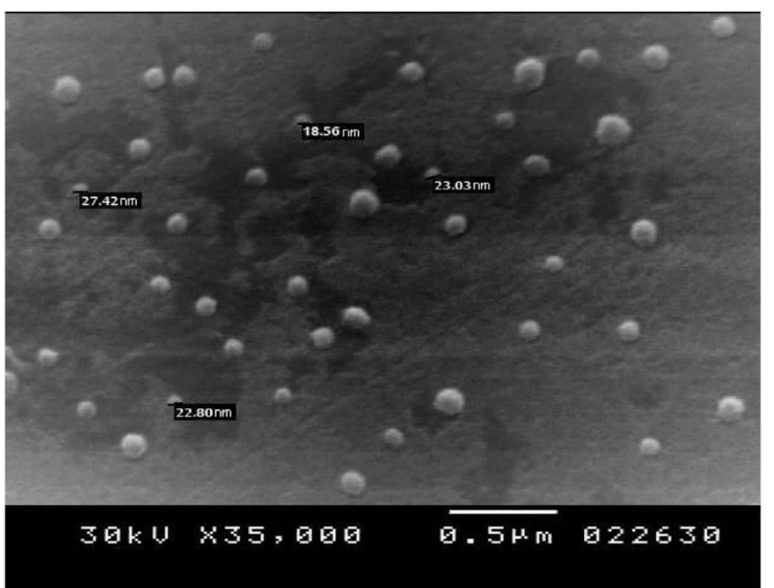

(b)

Figure 7. SEM of spherical Ag-NP obtained in [147] (a) and obtained in [155] (b). 
Very interesting results were presented in an article by Husain, Sardar, and Fatma [185], in which the authors studied the possibilities of "green synthesis" of Ag-NP using various cyanobacteria. According to the data presented in this publication, out of 30 microorganisms used for the biosynthesis of Ag-NP, and in nine cases, nanoparticles with shapes other than spherical, and, namely, triangular, pentagonal, hexagonal and cubic were described (Table 2). In the spectrum of each Ag-NP showed in [185], there was one absorption band in the violet, blue, or blue region of the visible spectrum with $\lambda_{\max }$ in the range $440-490 \mathrm{~nm}$. A larger assortment of elemental silver nanoparticle forms was noted by P. Singh et al. in [186], where in addition to the triangular, pentagonal, hexagonal and cubic already mentioned above, icosahedral and truncated triangle shapes were presented. In addition, that it is interesting, in this work, such diversity was achieved using only ONE microorganism: Bhargavaea indica (Figure 8). Despite such a considerable variation in the shape, as well as in size (30-100 nm) of Ag-NP obtained in [186], the authors of this work noted the presence of a band with only one $\lambda_{\max }$ value, namely $460 \mathrm{~nm}$, in all these nanoparticles. (Although there are strong reasons to believe that Ag-NPs of different shapes should have $\lambda_{\max }$ values that are different from each other). In some publications on the biosynthesis of Ag-NP using various microorganisms [169,171-179], the formation of nanoparticles with irregular shape was also noted (Figure 9).
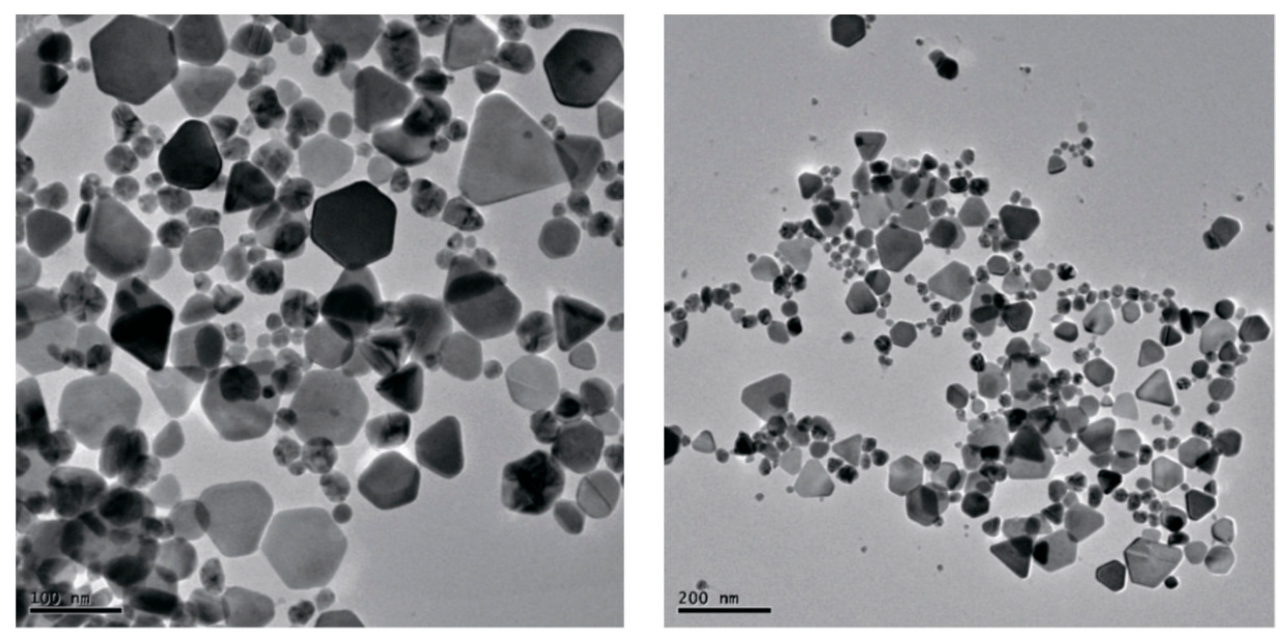

Figure 8. Transmission electron microscope (TEM) image of Ag-NP having various shapes and obtained in [186]. At a scale of $100 \mathrm{~nm}$ (left) and at a scale $200 \mathrm{~nm}$ (right)

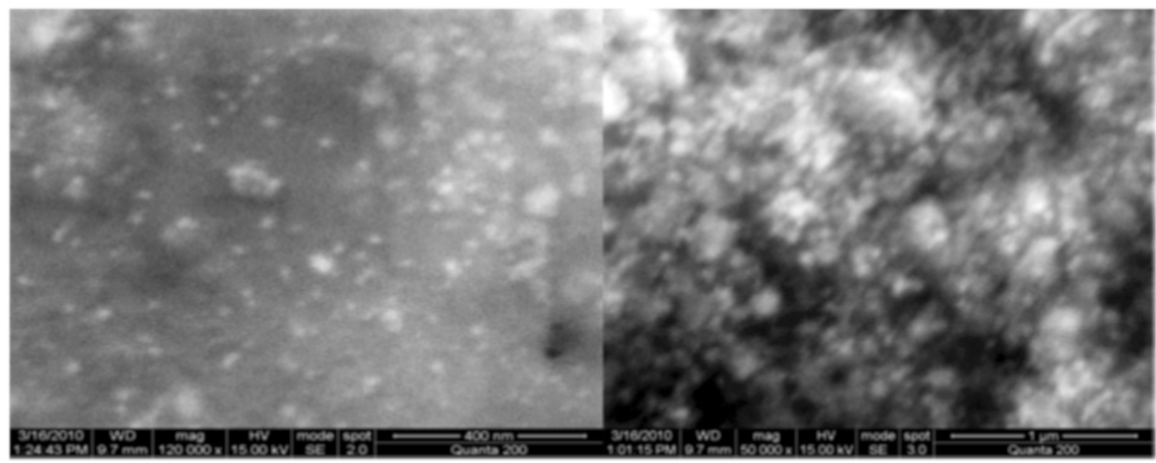

Figure 9. SEM image of Ag-NP having irregular shape and obtained in [176]. At a scale of $400 \mathrm{~nm}$ (left) and at a scale $1 \mathrm{~m}$ (right).

Along with microorganisms microscopic fungi were used as substrates for AgNP biosynthesis. First of all, it was fungi of the genus Aspergillis [120,126,139,167,168,170,182], Penicillium [131,142,145,152,162] and Fusarium $[118,119,121,148,181]$. This "green synthesis" of Ag-NP, as a rule, also led to the formation of pseudo-spherical Ag-NP with a wide variety of sizes (Table 2). So, in [118], as well as in [119], 
Ag-NP with such an external shape were obtained using Fusarium oxysporum fungi, and in the first of these works, silver nanoparticles were noticeably smaller than in the second (5-15 nm and 20-50 nm, respectively). Micro-fungi F. semitectum, were used as a substrate by the authors [181]; besides, Ag-NP with sizes in the range of 10-60 nm were received. Using fungi of the genus Aspergillis elemental silver nanoparticles with sizes ranging from $3 \mathrm{~nm}$ [126] to $140 \mathrm{~nm}$ [139] were described. The same situation took place for Ag-NP with using fungi of the genus Penicillium, but the size range was much smaller-from $8 \mathrm{~nm}$ [131] to $50 \mathrm{~nm}$ [152] (Table 2). Mostly get Ag-NP with the use of micro-fungi were also pseudo-spherical, but in some cases also took place the formation of small quantities of silver nanoparticles different geometric shapes [167,168,170,181,182]. For example, the authors of [181], along with pseudospherical Ag-NP, also obtained silver nanoparticles having a hexagonal shape. The formation of elemental silver nanoparticles having an irregular shape were observed in $[167,170]$. (An irregular shape of Ag-NP was also described by the authors [168] with a size of 550-650 nm, which although it refers to AGP aggregates, goes beyond the range accepted for nanoparticles (1-100) nm).

As with the use of plant extracts in Ag-NP biosynthesis, in most cases, for elemental silver nanoparticles synthesized using microorganisms, either a single absorption band with a maximum in the range of $400-460 \mathrm{~nm}$ in the visible spectral region or a "wing" band with a maximum in the UV region were also detected. Their colloidal solutions are also colored either in orange, or in red, or in red-brown. As an exception, only Ag-NP obtained by Manikprabhu and Lingappa in [173] using bacteria of the genus Staphylococcus, for which authors found the presence of two bands in the visible region of the spectrum, namely, violet with $\lambda_{\max }$ in the range $420-430 \mathrm{~nm}$ and in yellow-green with $\lambda_{\max }$ in the range of 550-570 nm was presented. However, the second of these bands was weakly expressed, as a result of which the Ag-NP obtained in [173] in color did not stand out among the other Ag-NP received with the use of microorganisms. These nanoparticles had sizes ranging from 28 to $50 \mathrm{~nm}$ and an irregular shape [173].

Concluding this section, we note that during the biosynthesis of Ag-NP using both plant extracts and microorganisms, it has not yet been possible to obtain such shapes of silver nanoparticles as nanorods, nanowires, or nanobars, which were once observed during physicochemical synthesis of Ag-NP, in particular, in the publications [187-189]. During this biosynthesis, Ag-NP particles with that unique "flower-like" shape that was described in the work cited above [109] have also not yet been discovered. On the biosynthesis of Ag-NP using various microorganisms, there is, in particular, a review article [114].

\section{Synthesis of Ag-NP Using Various Protein Products}

The literature contains a number of data showing the possibility of using for the synthesis of Ag-NP various products of animal origin, in particular polypeptide high molecular weight compounds (proteins). Owing to the large size of their molecules, the molecular mass of which (M) is tens and hundreds of thousands of carbon units (c.u., Daltons), their role in this process is reduced mainly to function (3), i.e. substrates that hinder the aggregation of already formed nanoparticles (although in principle their participation in the functions referred to in paragraph III (1-2) is not excluded); in that way, these nanoparticles are immobilized in masses of these substrates. An example of such a substrate is gelatin, which is the main component of various food (in particular, meat) jellies. As known [190-194], this natural compound is a polydisperse mixture of low molecular (molecular weight $\mathrm{M}=50,000-70,000$ c.u.) and high molecular ( $\mathrm{M}=200,000-300,000$ c.u.) polypeptides. The dimensional structure, which is now well studied [195-197], and in this structure there are many cavities of nanoscale size, which can serve as a kind of molecular nanoreactors. The reduction reaction $\mathrm{Ag}(\mathrm{I}) \rightarrow \mathrm{Ag}$ occurs namely in such cavities; in this case, some water-insoluble silver compound $\left(\mathrm{AgCl}, \mathrm{AgBr}, \mathrm{Ag}_{4}\left[\mathrm{Fe}(\mathrm{CN})_{6}\right]\right.$ et al) immobilized in a gelatin mass acts as a silver-containing precursor. The reducing agent is an organic or inorganic substance with strongly pronounced electron-donor properties. One of the most suitable for this purpose is tin dichloride $\mathrm{SnCl}_{2}$, which was used to obtain 
gelatin-immobilized Ag-NP in [198-201]. The reduction according to the Ag(I) $\rightarrow$ Ag scheme occurred in a strongly alkaline $(\mathrm{pH} 12)$ medium in the presence of reagents capable of forming fairly strong and water-soluble complexes with $\mathrm{Ag}(\mathrm{I})$ (thiocyanate anion $\mathrm{SCN}^{-}$, thiosulfate anion $\mathrm{S}_{2} \mathrm{O}_{3}{ }^{2-}$, ammonia $\mathrm{NH}_{3}$, ethylenediamine, monoethanolamine, etc.). Due to this fact, not $\mathrm{AgCl}, \mathrm{AgBr}$, or $\mathrm{Ag}_{4}\left[\mathrm{Fe}(\mathrm{CN})_{6}\right]$, but $\mathrm{Ag}(\mathrm{I})$ complexes with the inorganic and organic compounds named above, were actually reduced. The size of the pseudospherical Ag-NP obtained in this variant of biosynthesis is in the range from 10 to $40 \mathrm{~nm}$; this was first experimentally established in [199]. In this regard, when these nanoparticles are isolated from the gelatin matrix (for example, by the action of proteolytic enzymes, as described in [199], their aggregation naturally occurs; nevertheless, a significant part of these particles retains its former nano size. Details of the production of Ag-NP using such a specific method were presented in $[200,201]$. The idea that in the specific conditions of chemical processes in the gelatin matrix, as well as due to the above-mentioned specific structure of the gelatin itself, nanoparticles of a wide variety of chemical compounds can be formed in it, was expressed in a number of earlier works, particular in reviews [195-197,202,203].

Gelatin is not the only polypeptide substrate that can be used for this purpose; so, the various albumins are known for the synthesis of Ag-NP [204-206]. For example, the chicken egg protein was used for this purpose [204]; as a result, spherical Ag-NP with an average size of $\sim 20 \mathrm{~nm}$ and a maximum in the visible spectral region at $425 \mathrm{~nm}$ were obtained. The same substrate was used in [205], and in [206] — bovine serum albumin. Some publications concerning protein- and peptide-directed syntheses of inorganic materials, and, in particular, of elemental noble metal nanoparticles having various sizes and morphologies, can be found in review [207].

Another suitable substrate for the synthesis of Ag-NP can be a natural biopolymer chitin and chitosan derived from it. Chitosan is characterized by so-called mucoadhesive properties (ability to adhere to various mucous membranes) [208], which seems to be very important for creating drugs that enter the body through the mucous membranes [209-211]. In this connection, it seems appropriate to obtain chitosan-immobilized Ag-NP, which could be used as effective antibacterial agents. Now, however, only fragmentary information is available [212-220]. The influence of chitosan molecular weight on Ag-NP dimensional characteristics when they were formed in situ as a result of reduction of $\mathrm{AgNO}_{3}$ precursor in solution of this biopolymer was studied by Apryatina et al. [212,213]. It is very important that the authors $[212,213]$ were able to regulate the size of silver nanoparticles formed in the range from 8 to $12 \mathrm{~nm}$ by changing the molecular weight of chitosan (which also plays the role of a stabilizer of silver nanoparticles occuring during biosynthesis). The effect of the chitosan (M) molecular mass on the spectral characteristics of Ag-NP is also interesting: for example, at $M=40,000$ c.u. the absorption maximum in the visible spectrum $\left(\lambda_{\max }\right)$ is at $424 \mathrm{~nm}$, at $\mathrm{M}=127,000$ c.u., at $412 \mathrm{~nm}$, at $\mathrm{M}=165,000$ c.u., at $400 \mathrm{~nm}$, at $\mathrm{M}=240,000$ c.u., at $383 \mathrm{~nm}$. Herewith, Ag-NP formed in chitosan solutions with a higher molecular mass and having a size of $8 \mathrm{~nm}$, exhibit much more pronounced bactericidal activity than Ag-NP with a size of $12 \mathrm{~nm}[212,213]$. In a recently published paper [214] Uryupina with co-authors obtained pseudospherical Ag-NP with an average size of $65 \mathrm{~nm}$ using chitosan.

In [215-219], another derivative of chitin, namely 6-O-carboxymethylchitin, was tested as a substrate, and the use of $\gamma$-radiation from the ${ }^{60} \mathrm{Co}$ isotope contributed to the restoration of the $\mathrm{AgNO}_{3}$ precursor. As a result of the studies, new radiation-induced bactericidal metal-polymer nanosystems containing the above biopolymer and elemental silver nanoparticles, were created. Besides, by varying the dose of $\gamma$-radiation, as well as the degree of filling of the biopolymer macromolecules with $\mathrm{Ag}^{+}$ions, the authors of works $[215,216]$ were able to create macromolecular systems with silver nanoparticles $1-5 \mathrm{~nm}$ in size and, most importantly, to control these sizes during the experiment. The Ag-NP obtained in these studies, however, had an irregular shape. Research in the field of chitosan-immobilized Ag-NP undoubtedly requires continuation.

Thus, in principle, other high-molecular compounds belonging to the number of polysaccharides, for example, agar-agar, carrageenan and guar, can be used as substrates for the production of silver 
nanoparticles. In [220] pseudo-spherical Ag-NP using the guar as a substrate with sizes of 10-30 nm and $\lambda_{\max }$ in the range of $410-425 \mathrm{~nm}$ were received. However, according to the authors of this article, systematic research in this direction has not yet been undertaken.

\section{Bio Applications of Ag-NP}

Currently, elemental silver nanoparticles obtained by various methods are used in a very diverse fields of science and technology. Thus, an important area of application of Ag-NP is catalysis, which can be implemented in two versions: with the influence on the reaction system of electromagnetic radiation (photocatalysis) and without it. For example, in $[221,222]$ it was shown that Ag-NP on a $\mathrm{SiO}_{2}$ matrix exhibits catalytic properties in redox reactions involving benzene, carbon monoxide, some dyes, and, possibly, many other chemical compounds. In particular, benzene under these conditions is almost completely oxidized to phenol even when the Ag-NP content in the matrix is about 1 mass. \%. Reactions between sodium borohydride and dyes such as methylene blue and eosin, in the presence of Ag-NP in the reaction system, proceed at a very high rate, whereas in their absence such reactions practically do not take place. Besides, the $\mathrm{SiO}_{2}$ substrate actually serves only to prevent the aggregation of Ag-NP in a colloidal solution [222]. An important feature of Ag-NP is that they allow photocatalysis to be realized for the creation of resonant surface plasmons from light in the visible range, as well as to enhance the fluorescence intensity [223-228]. Owing to their stability and oxidation stability, elemental silver nanoparticles are widely used, for example, in electronics and photonics [229], as a biosensor [230], in biocatalysis [231], for protein coagulation [232] and for drug delivery [233]. A layer of silver nanoparticles covered cutlery, door handles and even a keyboard and mouse for computers; they are used to create new coatings and cosmetics, in filters of air-conditioning systems, in pools, showers and other places. The method of isotropic printing for the manufacture of silver microelectrodes is described, in which samples of electronic components with a minimum width of about $2 \mu \mathrm{m}$ were received by applying a concentrated paint consisting of silver nanoparticles on semiconductor, plastic and glass substrates [234].

The foregoing, however, relates mainly to those Ag-NP that were produced by chemical and physicochemical methods. And although Ag-NP obtained using "green synthesis" could also find their application in the above areas of science and technology, nevertheless, their modern practical application is related to the field of their production. As in this case biosynthesis of Ag-NP, as a rule, was carried out in laboratories of biological and/or biochemical section with participation of experts in the field of biochemistry and biotechnology; attention of researchers was focused on the application of Ag-NP in biology, first of all in medicine and pharmacology.

Currently, significant factual material related to bioapplications of Ag-NP already exists [235-238]. First of all, it is the possibility of antimicrobial activity of Ag-NP; according to the data presented in $[7,8]$, their antimicrobial effect is more expressed than that of penicillin, biomycin and other antibiotics, due to the inhibitory effect on antibiotic-resistant strains of bacteria. According to the data of these works, the effect of killing bacteria with preparations containing elemental silver nanoparticles is 1.500 times higher than phenol at the same concentration, and 3.5 times higher than mercury(II) dichloride (with much less toxicity). Ag-NP have an antimicrobial effect on many pathogenic microorganisms, such as Staphylococcus aureus, Streptococcus aureus, Proteus vulgaris, Pseudomonas aeruginosa and Escherichia coli: from bacteriostatic (ability to inhibit microbial reproduction) to bactericidal (ability to destroy microbes) [8]. Currently published works describe the use of biosynthesized Ag-NPs as antibacterial agents against a wide variety of microorganisms. So, in a number of works cited above devoted to the "green synthesis" of Ag-NP with the participation of plant extracts, a high efficiency of silver nanoparticles against pathogenic microorganisms of genera Bacillus $[43,73,74,81,87,103,106]$, Staphylococcus $[36,40,43,47,56,69,74,81,85,87,90,93,100,103,106,108]$, Pseudomonas $[40,43,47,69,77,85,93$, 100,103], Klebsiella [41,69,77,85,87,93,100,106], Escherichia [36,56,69,73,74,77,81,83,85,87,90,93,100,103, 108], Salmonella [74,77], Enterococcus [43] and Serratia [81], was noted. A similar Ag-NP effect received by various microorganisms and microscopic fungi on the genera Bacillus $[133,155,162,186]$, Staphylococcus [138, 
140,146,147,155,162,176,186], Pseudomonas [138,146,155], Klebsiella [176], Escherichia [133,155,162,176, 186], Salmonella [138,140,147,155,162,176,186], Enterococcus [138] and Streptococcus [140] was observed. The introduction of Ag-NP causes structural and morphological changes in cells that can lead to bacterial death. When silver nanoparticles come into contact with bacteria, they adhere to the cell wall and cell membrane, prevent replication and contribute to cell death [239]. Meanwhile, the so-called electronic effects are observed for Ag-NP with an average size of $10 \mathrm{~nm}$ or less, as a result of which their bactericidal activity increases sharply compared to that for Ag-NP with large dimensions [240]. In quantitative ratio, this effect is different for each specific type of cell, since, on the one hand, the composition of their cell membranes varies widely, on the other hand, with a decrease in the size of Ag-NP, their reactivity increases due to an increase in their surface area and reduce their volume. According to work [108] the discovered silver nano-wedges, due to their unique pointed shape, act on any microorganisms like real "daggers", tearing their bodies apart. Therefore, such Ag-NP with a similar form may be promising candidates for wide range of biomedical applications, and especially in the manufacture of antibacterial drugs. High fungicidal activity of biosynthesized Ag-NP on some microscopic fungi $[108,119,126,139]$ was shown. But it is noteworthy that, apparently, there are no works devoted to the biosynthesis of Ag-NP with the participation of micro-fungi in which the authors pointed to the fungicidal activity of the obtained Ag-NP to the micro-fungi, by which these nanoparticles were synthesized.

An important fact is that clearly expressed anticancer activity of silver nanoparticles was identified [52,54,61,70,73,79,87,88,101,156,162]. In [241], and Ag-NP were proposed for cancer diagnosis and drug standards. In [242], chemotherapeutic anticancer drugs were developed with photo-soluble linkers that "attached" them to a substrate on the surface of Ag-NP. The principle of action of such drugs is reduced to destruction under the influence of UV radiation, resulting in its active form, which has a destructive effect on cancer cells [242]. Earlier, an alternative approach, in which the anticancer drug "attached" directly to the functionalized surface of Ag-NP, was proposed [243]. The advantages of cancer treatment methods described in [242,243] are that, on the one hand, the drug is transported into the patient's body without the use of any toxic compounds, on the other hand, it is selectively released precisely in the affected organ. Ag-NP can also be useful for overcoming multidrug resistance, which often prevents the delivery of the right drug to the affected organ [244].

Ag-NP seems to be characterized by a highly synergistic bactericidal action in combination with such well-known antibiotics as penicillin, ampicillin, erythromycin, clindamycin and vancomycin; such a phenomenon has been observed, for example, against bacteria of the genus Staphylococcus and Escherichia [245]. It should be noted that preparations based on elemental nanoparticles are widely used in bone transplants for the treatment of burns, because Ag-NP associated with the implant provide better antimicrobial activity and contribute to a significant reduction in the number of scars arising in the healing process of the affected tissue. Owing to antimicrobial activity, elemental silver nanoparticles find a certain application also in the food industry and in food technologies, described in [246,247].

Another possibility for the application Ag-NP is their use as part of larvicidal compositions. In particular, it was proposed to use biosynthesized Ag-NP against malaria mosquitoes of the genus Anopheles [33,105,248-253], and pathogens of malaria, Plasmodium falciparum [254], and mosquito carriers of yellow fever, the genus Aedes and Culex [104-106,248,249,251-253,255]. (It is interesting that graphene was used in $[251,254]$ as one of the components of such preparations). However, the number of works devoted to the larvicidal (and insecticidal) activity of biosynthesized Ag-NP is still relatively small compared to that for the works about the antibacterial activity of these NP.

Nevertheless, it should be noted that Ag-NP is still toxic to the human body. Because of Ag-NP dissolves to form $\mathrm{Ag}^{+}$ions, which are known to have toxic effects [256], some studies have been conducted to determine whether Ag-NP toxicity is a result of the release of silver ions or is associated with the nanoparticles themselves $[257,258]$. The results of these studies indicate that elemental silver nanoparticles can indeed cause allergies. However, these results do not exclude the possibility that the toxicity of Ag-NP is no less associated with the formation of silver ions in cells, because according 
to [259], Ag-NP and $\mathrm{Ag}^{+}$ions have almost the same cytotoxicity. The authors of [260] came to the same conclusion: the combination of Ag-NP and $\mathrm{Ag}^{+}$is responsible for the toxic effect of silver nanoparticles; in addition, a toxic effect on cells was shown for the Ag-NP regardless of free silver ions. On the other hand, the toxicity of Ag-NP in human cells is due to oxidative stress and inflammation caused by the formation of reactive oxygen species stimulated by either $\mathrm{Ag}-\mathrm{NP}, \mathrm{Ag}^{+}$ions, or both [261]. According to the authors of [262], the introduction of Ag-NP into tissue cells leads to the formation of free radicals, which pose a potential health risk.

\section{Conclusions}

Thus, the perspectives of the biosynthesis of Ag-NP look very impressive. The list of biological substrates that have so far been used in published works is extremely long, and in this review paper it is impossible even to quote all these publications. However, now the development and improvement of these methods using those discussed biological substrates, the control of the size, shape and degree of dispersion of biosynthesized Ag-NP, cannot yet be considered to have been adequately determined experimentally. That is why, for the implementation of the controlled biosynthesis of Ag-NP with predetermined target parameters, undoubtedly, some new principles and methodological approaches should be elaborated. For this, a thorough knowledge of the mechanism of the process of nanoparticle biosynthesis is necessary in general and of Ag-NP in particular, the specifics of which in most cases has remained unexplored. Each of these bio-syntheses requires information about the effect on the process of concentration-time and temperature parameters used in the experiment, which in most published works is scattered and clearly insufficient to make complete conclusions. A very important task is also to increase the yield of the target product (i.e., synthesized Ag-NP). Finally, it is very important to improve existing methods and develop new methods of isolating nanoparticles from the parent systems in which they were formed (which may be necessary to produce commercially available products containing these nanoparticles).

Author Contributions: Introduction, Sections 1-3 were written by O.V.M., Section 5-by E.O.M., Sections 4 and 6 and conclusion, were written both co-authors.

Funding: This research received no external funding.

Acknowledgments: This work was supported by project No. 4.5784.2017/8.9 to the competitive part of the state task of the Russian Federation on the 2017-2019 years.

Conflicts of Interest: The authors declare no conflict of interest, financial or otherwise.

\section{References}

1. Barber, D.J.; Freestone, I.C. An investigation of the origin of the colour of the lycurgus cup by analytical transmission electron microscopy. Archaeom. 1990, 32, 33-45. [CrossRef]

2. Holy Water. Available online: https://en.wikipedia.org/wiki/Holy_water (accessed on 25 September 2019).

3. Nägeli, K.W. Über oligodynamische Erscheinungen in lebenden Zellen; Allgemeine schweizerische Gesellschaft für die gesammten Naturwissenschaften: Zürich, Switzerland, 1893.

4. Henglein, A. Small-particle research: Physicochemical properties of extremely small colloidal metal and semiconductor particles. Chem. Rev. 1989, 89, 1861-1873. [CrossRef]

5. Shrestha, R.; Joshi, D.R.; Gopali, J.; Piya, S. Oligodynamic fraction of silver, copper and brass on enteric bacteria isolated from water of Kathmandu Valley. Nepal J. Sci. Technol. 2009, 10, 189-193. [CrossRef]

6. Rai, M.; Yadav, A.; Gade, A. Silver nanoparticles as a new generation of antimicrobials. Biotechnol. Adv. 2009, 27, 76-83. [CrossRef] [PubMed]

7. Im, S.H.; Lee, Y.T.; Wiley, B.; Xia, Y. Large-scale synthesis of silver nanocubes: The role of $\mathrm{HCl}$ in promoting cube perfection and monodispersity. Angew. Chem. Int. Ed. 2005, 44, 2154-2157. [CrossRef] [PubMed]

8. Landsdown, A.B.G. Silver in Healthcare: Its Antimicrobial Efficacy And Safety in Use; Royal Society of Chemistry: Cambridge, UK, May 2010.

9. Ghorbani, H.R.; Safekordi, A.A.; Attar, H.; Rezayat Sorkhabadi, S.M. Biological and non-biological methods for silver nanoparticles synthesis. Chem. Biochem. Eng. Quart. 2011, 25, 317-326. 
10. Lee, H.J.; Yeo, S.Y.; Jeong, S.H. Antibacterial effect of nanosized silver colloidal solution on textile fabrics. J. Mater. Sci. 2003, 38, 2199-2204. [CrossRef]

11. Zhang, J.-P.; Chen, P.; Sun, C.-H.; Hu, X.-J. Sonochemical synthesis of colloidal silver catalysts for reduction of complexing silver in DTR system. Appl. Catal. A Gen. 2004, 266, 49-54. [CrossRef]

12. Zhang, W.; Qiao, X.; Chen, J.; Wang, H. Preparation of silver nanoparticles in water-in-oil AOT reverse micelles. J. Colloid Interface Sci. 2006, 302, 370-373. [CrossRef]

13. Kirm, I.; Cesteros, Y.; Salagre, P.; Sueiras, J.E.; Chimentão, R.J.; Rodríguez, X.; Medina, F. Different morphologies of silver nanoparticles as catalysts for the selective oxidation of styrene in the gas phase. Chem. Commun. 2004, 4, 846.

14. He, B.; Tan, J.J.; Liew, K.Y.; Liu, H. Synthesis of size controlled Ag nanoparticles. J. Mol. Catal. A: Chem. 2004, 221, 121-126. [CrossRef]

15. Kouvaris, P.; Delimitis, A.; Zaspalis, V.; Papadopoulos, D.; Tsipas, S.A.; Michailidis, N.; Tsipas, S.A. Green synthesis and characterization of silver nanoparticles produced using Arbutus Unedo leaf extract. Mater. Lett. 2012, 76, 18-20. [CrossRef]

16. Shameli, K.; Bin Ahmad, M.; Al-Mulla, E.A.J.; Ibrahim, N.A.; Shabanzadeh, P.; Rustaiyan, A.; Abdollahi, Y.; Bagheri, S.; Abdolmohammadi, S.; Usman, M.S.; et al. Green Biosynthesis of Silver Nanoparticles Using Callicarpa maingayi Stem Bark Extraction. Molecules 2012, 17, 8506-8517. [CrossRef] [PubMed]

17. Meng, X.K.; Tang, S.C.; Vongehr, S. A review on diverse silver nanostructures. J. Mater. Sci. Technol. 2010, 26, 487-522. [CrossRef]

18. Cao, G. Synthesis, properties and applications. In Nanostructures and Nanomaterials; Imperial College Press: London, UK, April 2004.

19. Krutyakov, Y.A.; Kudrinskiy, A.A.; Olenin, A.Y.; Lisichkin, G.V. Synthesis and properties of silver nanoparticles: Advances and prospects. Russ. Chem. Rev. 2008, 77, 233-257. [CrossRef]

20. Olenin, A.Y.; Lisichkin, G.V. Metal nanoparticles in condensed the bulk and surface structural dynamics. Russ. Chem. Rev. 2011, 80, 605-630. [CrossRef]

21. Murphy, C.J.; Gole, A.M.; Hunyadi, S.E.; Orendorff, C.J. One-dimensional colloidal gold and silver nanostructures. Inorg. Chem. 2006, 45, 7544-7554. [CrossRef]

22. Wiley, B.; Sun, Y.G.; Mayers, B.; Xia, Y.N. Shape-controlled synthesis of metal nano-structures: The case of silver. Chem. A Eur. J. 2005, 11, 454-463. [CrossRef]

23. Khodashenas, B.; Ghorbani, H.R. Synthesis of silver nanoparticles with different shapes (review). Arabian J. Chem 2015. [CrossRef]

24. Cai, X.; Zhai, A. Preparation of microsized silver crystals with different morphologies by a wet-chemical method. Rare Met. 2010, 29, 407-412. [CrossRef]

25. Shankar, S.S.; Ahmad, A.; Sastry, M. Geranium leaf assisted biosynthesis of silver nanoparticles. Biotechnol. Prog. 2003, 19, 1627-1631. [CrossRef] [PubMed]

26. Ankamwar, B.; Damle, C.; Ahmad, A.; Sastry, M. Biosynthesis of gold and silver nanoparticles using Emblica Officinalis fruit extract, their phase transfer and transmetallation in an organic solution. J. Nanosci. Nanotechnol. 2005, 5, 1665-1671. [CrossRef] [PubMed]

27. Chandran, S.P.; Chaudhary, M.; Pasricha, R.; Ahmad, A.; Sastry, M. Synthesis of Gold Nanotriangles and Silver Nanoparticles Using Aloe vera Plant Extract. Biotechnol. Prog. 2006, 22, 577-583. [CrossRef] [PubMed]

28. Li, S.; Shen, Y.; Xie, A.; Yu, X.; Qiu, L.; Zhang, L.; Zhang, Q. Green synthesis of silver nanoparticles using Capsicum annuum L. extract. Green Chem. 2007, 9, 852. [CrossRef]

29. Cruz, D.; Falé, P.L.; Mourato, A.; Vaz, P.D.; Serralheiro, M.L.; Lino, A.R.L. Preparation and physicochemical characterization of Ag nanoparticles biosynthesized by Lippia citriodora (Lemon Verbena). Colloids Surf. B Biointerfaces 2010, 81, 67-73. [CrossRef] [PubMed]

30. Krishnaraj, C.; Jagan, E.; Rajasekar, S.; Selvakumar, P.; Kalaichelvan, P.; Mohan, N. Synthesis of silver nanoparticles using Acalypha indica leaf extracts and its antibacterial activity against water borne pathogens. Colloids Surfaces B Biointerfaces 2010, 76, 50-56. [CrossRef] [PubMed]

31. Gopinath, V.; Priyadarshini, S.; Venkatkumar, G.; Saravanan, M.; Ali, D.M. Antibacterial silver nanoparticles. Pharm. Nanotechnol. 2015, 3, 26-34. [CrossRef]

32. Prakash, P.; Gnanaprakasam, P.; Emmanuel, R.; Arokiyaraj, S.; Saravanan, M. Green synthesis of silver nanoparticles from leaf extract of Mimusops elengi, Linn. for enhanced antibacterial activity against multi drug resistant clinical isolates. Colloids Surfaces B Biointerfaces 2013, 108, 255-259. [CrossRef] 
33. Arokiyaraj, S.; Kumar, V.D.; Elakya, V.; Kamala, T.; Park, S.K.; Ragam, M.; Saravanan, M.; Bououdina, M.; Arasu, M.V.; Kovendan, K.; et al. Biosynthesized silver nanoparticles using floral extract of Chrysanthemum indicum L.-Potential for malaria vector control. Environ. Sci. Pollut. Res. 2015, 22, 9759-9765. [CrossRef]

34. Huang, J.; Li, Q.; Sun, D.; Lu, Y.; Su, Y.; Yang, X.; Wanh, H.; Wang, Y.; Shao, W.; He, N.; et al. Biosynthesis of silver and gold nanoparticles by novel sundried Cinnamomum canphora leaf. Nanotechnology 2007, 18, 1-11. [CrossRef]

35. Jha, A.K.; Kumar, V.; Prasad, K. Biosynthesis of silver nanoparticles using Eclipta leaf. Biotechnol. Prog. 2009, 25, 1476-1479. [CrossRef] [PubMed]

36. Singhal, G.; Bhavesh, R.; Kasariya, K.; Sharma, A.R.; Singh, R.P. Biosynthesis of silver nanoparticles using Ocimum sanctum (Tulsi) leaf extract and screening its antimicrobial activity. J. Nanoparticle Res. 2011, 13, 2981-2988. [CrossRef]

37. Udayasoorian, C.; Vinoth, K.K.; Jayabalakrishnan, R.M. Extracellular synthesis of silver nanoparticles using leaf extract of Cassia auriculata. Dig. J Nano. Biostruct 2011, 6, 279-283.

38. Mano, P.M.; Karunai, S.B.; John, P.J.A. Green synthesis of silver nanoparticles from the leaf extracts of euphorbia hirta and nerium indicum. Dig. J. Nanomater. Biostruct. 2011, 6, 869-877.

39. Bangale, S.; Ghotekar, S. Bio-fabrication of silver nanoparticles using rosa chinensis 1. extract for antibacterial activities. Int. J. Nano Dimens. 2019, 10, 217-224.

40. Gopinath, V.; Mubarak, A.D.; Priyadarshini, S.; Priyadharsshini, N.M.; Thajuddin, N.; Velusamy, P. Biosynthesis of silver nanoparticles from and its antimicrobial activity: A novel biological approach. Colloids Surf. B Biointerfaces 2012, 96, 69-74. [CrossRef] [PubMed]

41. Ghosh, S.; Patil, S.; Ahire, M.; Kitture, R.; Kale, S.; Pardesi, K.; Cameotra, S.S.; Bellare, J.; Dhavale, D.D.; Jabgunde, A.; et al. Synthesis of silver nanoparticles using dioscorea bulbifera tuber extract and evaluation of its synergistic potential in combination with antimicrobial agents. Int. J. Nanomed. 2012, 7, 483-496.

42. Devi, J.; Bhimba, V.; Ratnam, K. Anticancer activity of silver nanoparticles synthesized by the seaweed Ulva lactucain vitro. Sci. Rep. 2012, 1, 242-248.

43. Geethalakshmi, R.; Sarada, D. Gold and silver nanoparticles from Trianthema decandra: Synthesis, characterization, and antimicrobial properties. Int. J. Nanomed. 2012, 7, 5375-5384. [CrossRef]

44. Valli, J.S.; Vaseeharan, B. Biosynthesis of silver nanoparticles by Cissus quadrangularis extracts. Mater. Lett. 2012, 82, 171-173. [CrossRef]

45. Dipankar, C.; Murugan, S. The green synthesis, characterization and evaluation of the biological activities of silver nanoparticles synthesized from Iresine herbstii leaf aqueous extracts. Colloids Surf. B Biointerfaces 2012, 98, 112-119. [CrossRef] [PubMed]

46. Ahmad, N.; Sharma, S. Green Synthesis of Silver Nanoparticles Using Extracts of Ananas comosus. Green Sustain. Chem. 2012, 2, 141-147. [CrossRef]

47. Kora, A.J.; Sashidhar, R.; Arunachalam, J.; Kora, D.A.J. Aqueous extract of gum olibanum (Boswellia serrata): A reductant and stabilizer for the biosynthesis of antibacterial silver nanoparticles. Process. Biochem. 2012, 47, 1516-1520. [CrossRef]

48. Bindhu, M.; Umadevi, M. Synthesis of monodispersed silver nanoparticles using Hibiscus cannabinus leaf extract and its antimicrobial activity. Spectrochim. Acta Part A Mol. Biomol. Spectrosc. 2013, 101, 184-190. [CrossRef] [PubMed]

49. Tamuly, C.; Hazarika, M.; Borah, S.C.; Das, M.R.; Boruah, M.P.; Das, D.M.R. In situ biosynthesis of Ag, $\mathrm{Au}$ and bimetallic nanoparticles using Piper pedicellatum C.DC: Green chemistry approach. Colloids Surf. B Biointerfaces 2013, 102, 627-634. [CrossRef]

50. Tran, T.T.T.; Vu, T.T.H.; Nguyen, T.H.; Nguyễn, T.H. Biosynthesis of silver nanoparticles using Tithonia diversifolia leaf extract and their antimicrobial activity. Mater. Lett. 2013, 105, 220-223. [CrossRef]

51. Tripathi, R.; Kumar, N.; Shrivastav, A.; Singh, P.; Shrivastav, B. Catalytic activity of biogenic silver nanoparticles synthesized by ficus panda leaf extract. J. Mol. Catal. B: Enzym. 2013, 96, 75-80. [CrossRef]

52. Shawkey, A.M.; Rabeh, M.A.; Abdulall, A.K.; Abdellatif, A.O. Green nanotechnology: Anticancer activity of silver nanoparticles using Citrullus colocynthis aqueous extracts. Adv. Life Sci. Technol. 2013, 13, 60-70.

53. Firdhouse, M.J.; Lalitha, P. Biosynthesis of silver nanoparticles using the extract of Alternanthera sessilis-Antiproliferative effect against prostate cancer cells. Cancer Nanotechnol. 2013, 4, 137-143. [CrossRef] 
54. Jeyaraj, M.; Rajesh, M.; Arun, R.; MubarakAli, D.; Sathishkumar, G.; Sivanandhan, G.; Dev, G.K.; Manickavasagam, M.; Premkumar, K.; Thajuddin, N.; et al. An investigation on the cytotoxicity and caspase-mediated apoptotic effect of biologically synthesized silver nanoparticles using Podophyllum hexandrum on human cervical carcinoma cells. Colloids Surf. B Biointerfaces 2013, 102, 708-717. [CrossRef]

55. Mariselvam, R.; Ranjitsingh, A.; Nanthini, A.U.R.; Kalirajan, K.; Padmalatha, C.; Selvakumar, P.M. Green synthesis of silver nanoparticles from the extract of the inflorescence of Cocos nucifera (Family: Arecaceae) for enhanced antibacterial activity. Spectrochim. Acta Part A Mol. Biomol. Spectrosc. 2014, 129, 537-541. [CrossRef] [PubMed]

56. Khalil, M.M.; Ismail, E.H.; El-Baghdady, K.Z.; Mohamed, D. Green synthesis of silver nanoparticles using olive leaf extract and its antibacterial activity. Arab. J. Chem. 2014, 7, 1131-1139. [CrossRef]

57. Shanmugam, N.; Rajkamal, P.; Cholan, S.; Kannadasan, N.; Sathishkumar, K.; Viruthagiri, G.; Sundaramanickam, A. Biosynthesis of silver nanoparticles from the marine seaweed Sargassum wightii and their antibacterial activity against some human pathogens. Appl. Nanosci. 2014, 4, 881-888. [CrossRef]

58. Mukherjee, S.; Chowdhury, D.; Kotcherlakota, R.; Patra, S.; Bhadra, M.P.; Sreedhar, B.; Patra, C.R. Potential Theranostics Application of Bio-Synthesized Silver Nanoparticles (4-in-1 System). Theranostics 2014, 4, 316-335. [CrossRef] [PubMed]

59. Reddy, N.J.; Vali, D.N.; Rani, M.; Rani, S.S. Evaluation of antioxidant, antibacterial and cytotoxic effects of green synthesized silver nanoparticles by Piper longum fruit. Mater. Sci. Eng. C 2014, 34, 115-122. [CrossRef] [PubMed]

60. Sathiya, C.; Akilandeswari, S. Fabrication and characterization of silver nanoparticles using delonix elata leaf broth. Spectrochim. Acta Part A Mol. Biomol. Spectrosc. 2014, 128, 337-341. [CrossRef] [PubMed]

61. Kumar, C.M.K.; Yugandhar, P.; Savithramma, N. Biological synthesis of silver nanoparticles from Adansonia digitata L. fruit pulp extract, characterization, and its antimicrobial properties. J. Intercultur. Ethnopharm. 2016, 5, 79-84. [CrossRef] [PubMed]

62. Ramesh, P.; Kokila, T.; Geetha, D. Plant mediated green synthesis and antibacterial activity of silver nanoparticles using Emblica officinalis fruit extract. Spectrochim. Acta Part A Mol. Biomol. Spectrosc. 2015, 142, 339-343. [CrossRef]

63. Sharma, D.; Ledwani, L.; Bhatnagar, N. Antimicrobial and cytotoxic potential of silver nanoparticles synthesized using Rheum emodi roots extract. Ann. West. Univ. Timisoara 2015, 24, 121-135.

64. Pandian, A.M.K.; Karthikeyan, C.; Rajasimman, M.; Dinesh, M. Synthesis of silver nanoparticle and its application. Ecotoxicol. Environ. Saf. 2015, 121, 211-217. [CrossRef]

65. Govindaraju, K.; Krishnamoorthy, K.; Alsagaby, S.A.; Singaravelu, G.; Premanathan, M. Green synthesis of silver nanoparticles for selective toxicity towards cancer cells. IET Nanobiotechnology 2015, 9, 325-330. [CrossRef]

66. Sre, P.R.; Reka, M.; Poovazhagi, R.; Kumar, M.A.; Murugesan, K. Antibacterial and cytotoxic effect of biologically synthesized silver nanoparticles using aqueous root extract of Erythrina indica lam. Spectrochim. Acta Part A Mol. Biomol. Spectrosc. 2015, 135, 1137-1144.

67. Mata, R.; Nakkala, J.R.; Sadras, S.R. Catalytic and biological activities of green silver nanoparticles synthesized from Plumeria alba (frangipani) flower extract. Mater. Sci. Eng. C 2015, 51, 216-225. [CrossRef] [PubMed]

68. Chanthini, A.B.; Balasubramani, G.; Ramkumar, R.; Sowmiya, R.; Balakumaran, M.D.; Kalaichelvan, P.T.; Perumal, P. Structural characterization, antioxidant and in vitro cytotoxic properties of seagrass, Cymodocea serrulata (R. Br.) Asch. \& Magnus mediated silver nanoparticles. J. Photochem. Photobiol. B Biol. 2015, 153, 145-152.

69. Ahmed, M.J.; Murtaza, G.; Mehmood, A.; Bhatti, T.M. Green synthesis of silver nanoparticles using leaves extract of Skimmia laureola: Characterization and antibacterial activity. Mater. Lett. 2015, 153, 10-13. [CrossRef]

70. Patra, S.; Mukherjee, S.; Barui, A.K.; Ganguly, A.; Sreedhar, B.; Patra, C.R. Green synthesis, characterization of gold and silver nanoparticles and their potential application for cancer therapeutics. Mater. Sci. Eng. C 2015, 53, 298-309. [CrossRef] [PubMed]

71. Ahlawat, J.; Sehrawat, A.R. Biological synthesis of silver nanoparticles using aqueous leaf extract of Capparis decidua (FORSK.) EDGEW: A better alternative. J Pharm Res. 2015, 11, $244-249$.

72. Ahmed, S.; Saifullah; Ahmad, M.; Swami, B.L.; Ikram, S. Green synthesis of silver nanoparticles using Azadirachta indica aqueous leaf extract. J. Radiat. Res. Appl. Sci. 2016, 9, 1-7. [CrossRef] 
73. Mittal, A.K.; Thanki, K.; Jain, S.; Banerjee, U.C. Comparative studies of anticancer and antimicrobial potential of bioinspired silver and silver-selenium nanoparticles. Appl. Nanomedicine 2016, 1, 1-6.

74. Benakashani, F.; Allafchian, A.; Jalali, S.; Allafchian, A. Biosynthesis of silver nanoparticles using Capparis spinosa L. leaf extract and their antibacterial activity. Karbala Int. J. Mod. Sci. 2016, 2, 251-258. [CrossRef]

75. Lateef, A.; Azeez, M.A.; Asafa, T.B.; Yekeen, T.A.; Akinboro, A.; Oladipo, I.C.; Azeez, L.; Ajibade, S.E.; Ojo, S.A.; Gueguim-Kana, E.B.; et al. Biogenic synthesis of silver nanoparticles using a pod extract of Cola nitida: Antibacterial and antioxidant activities and applicationas a paint additive. J. Taibah Univ. Sci. 2016, 10, 551-562. [CrossRef]

76. Salehi, S.; Shandiz, S.A.S.; Ghanbar, F.; Darvish, M.R.; Ardestani, M.S.; Mirzaie, A.; Jafari, M. Phytosynthesis of silver nanoparticles using Artemisia marschalliana Sprengel aerial part extract and assessment of their antioxidant, anticancer, and antibacterial properties. Int. J. Nanomed. 2016, 11, 1835-1846.

77. Soman, S.; Ray, J. Silver nanoparticles synthesized using aqueous leaf extract of Ziziphus oenoplia (L.) Mill: Characterization and assessment of antibacterial activity. J. Photochem. Photobiol. B Boil. 2016, 163, 391-402. [CrossRef] [PubMed]

78. Khanra, K.; Panja, S.; Choudhuri, I.; Chakraborty, A.; Bhattacharyya, N. Antimicrobial and cytotoxicity effect of silver nanoparticle synthesized by Croton bonplandianum Baill. leaves. Nanomed. J. 2016, 3, 15-22.

79. He, Y.; Du, Z.; Ma, S.; Liu, Y.; Li, D.; Huang, H.; Jiang, S.; Cheng, S.; Wu, W.; Zhang, K.; et al. Effects of green-synthesized silver nanoparticles on lung cancer cells in vitro and grown as xenograft tumors in vivo. Int. J. Nanomed. 2016, 11, 1879-1887. [CrossRef] [PubMed]

80. Kumar, B.; Smita, K.; Seqqat, R.; Benalcazar, K.; Grijalva, M.; Cumbal, L. In vitro evaluation of silver nanoparticles cytotoxicity on Hepatic cancer (Hep-G2) cell line and their antioxidant activity: Green approach for fabrication and application. J. Photochem. Photobiol. B Boil. 2016, 159, 8-13. [CrossRef] [PubMed]

81. Singh, T.; Jyoti, K.; Patnaik, A.; Singh, A.; Chauhan, R.; Chandel, S. Biosynthesis, characterization and antibacterial activity of silver nanoparticles using an endophytic fungal supernatant of Raphanus sativus. J. Genet. Eng. Biotechnol. 2017, 15, 31-39. [CrossRef]

82. Mehmood, A.; Murtaza, G.; Bhatti, T.M.; Kausar, R. Phyto-mediated synthesis of silver nanoparticles from Melia azedarach L. leaf extract: Characterization and antibacterial activity. Arab. J. Chem. 2017, 10, S3048-S3053. [CrossRef]

83. Raja, S.; Ramesh, V.; Thivaharan, V.; Vinayagam, R. Green biosynthesis of silver nanoparticles using Calliandra haematocephala leaf extract, their antibacterial activity and hydrogen peroxide sensing capability. Arab. J. Chem. 2017, 10, 253-261. [CrossRef]

84. Bagherzade, G.; Tavakoli, M.M.; Namaei, M.H. Green synthesis of silver nanoparticles using aqueous extract of saffron (Crocus sativus L.) wastages and its antibacterial activity against six bacteria. Asian Pac. J. Trop. Biomed. 2017, 7, 227-233. [CrossRef]

85. Elemike, E.E.; Fayemi, O.E.; Ekennia, A.C.; Onwudiwe, D.C.; Ebenso, E.E. Silver nanoparticles mediated by costus afer leaf extract: Synthesis, antibacterial, antioxidant and electrochemical properties. Molecules 2017, 22, 701. [CrossRef] [PubMed]

86. Devanesan, S.; AlSalhi, M.S.; Balaji, R.V.; A Ranjitsingh, A.J.; Ahamed, A.; Alfuraydi, A.A.; Alqahtani, F.Y.; Aleanizy, F.S.; Othman, A.H. Antimicrobial and cytotoxicity effects of synthesized silver nanoparticles from punica granatum peel extract. Nanoscale Res. Lett. 2018, 13, 315. [CrossRef] [PubMed]

87. Lakshmanan, G.; Sathiyaseelan, A.; Kalaichelvan, P.T.; Murugesan, K. Plant-mediated synthesis of silver nanoparticles using fruit extract of Cleome viscosa L.: Assessment of their antibacterial and anticancer activity. Karbala Int. J. Mod. Sci. 2018, 4, 61-68.

88. Dehghanizade, S.; Arasteh, J.; Mirzaie, A. Green synthesis of silver nanoparticles using Anthemis atropatana extract: Characterization and in vitro biological activities. Artif. Cells Nanomed. Biotechnol. 2018, 46, 160-168. [CrossRef] [PubMed]

89. Satyavani, K.; Gurudeeban, S.; Ramanathan, T.; Balasubramanian, T. Biomedical potential of silver nanoparticles synthesized from calli cells of Citrullus colocynthis (L.) Schrad. J. Nanobiotechnol. 2011, 9, 43. [CrossRef]

90. Gomathi, M.; Rajkumar, P.; Prakasam, A.; Ravichandran, K. Green synthesis of silver nanoparticles using Datura stramonium leaf extract and assessment of their antibacterial activity. Resour. Technol. 2017, 3, $280-284$. [CrossRef] 
91. Suman, T.; Rajasree, S.R.; Kanchana, A.; Elizabeth, S.B. Biosynthesis, characterization and cytotoxic effect of plant mediated silver nanoparticles using Morinda citrifolia root extract. Colloids Surf. B Biointerfaces 2013, 106, 74-78. [CrossRef]

92. Arunachalam, K.; Shanmuganathan, B.; Sreeja, P.S.; Parimelazhagan, T. Phytosynthesis of silver nanoparticles using the leaves extract of ficus talbot king and evaluation of antioxidant and antibacterial activities. Environ. Sci. Pollut. Res. Int. 2015, 22, 18066-18075. [CrossRef]

93. Logeswari, P.; Silambarasan, S.; Abraham, J. Ecofriendly synthesis of silver nanoparticles from commercially available plant powders and their antibacterial properties. Sci. Iran. F 2013, 20, 1049-1054.

94. Arokiyaraj, S.; Vincent, S.; Saravanan, M.; Lee, Y.; Oh, Y.K.; Kim, K.H. Green synthesis of silver nanoparticles using rheum palmatum root extract and their antibacterial activity against staphylococcus aureus and pseudomonas aeruginosa. Artif. Cells Nanomed. Biotechnol. 2017, 45, 372-379. [CrossRef]

95. Kasithevar, M.; Saravanan, M.; Prakash, P.; Kumar, H.; Ovais, M.; Barabadi, H.; Shinwari, Z.K. Green synthesis of silver nanoparticles using alysicarpus monilifer leaf extract and its antibacterial activity against MRSA and CoNS isolates in HIV patients. J. Interdiscip. Nanomed. 2017, 2, 131-141. [CrossRef]

96. Mittal, A.K.; Tripathy, D.; Choudhary, A.; Aili, P.K.; Chatterjee, A.; Singh, I.P.; Banerjee, U.C. Bio-synthesis of silver nanoparticles using potentilla fulgens wall. ex Hook. and its therapeutic evaluation as anticancer and antimicrobial agent. Mater. Sci. Eng. C 2015, 53, 120-127. [CrossRef] [PubMed]

97. Sukirtha, R.; Priyanka, K.M.; Antony, J.J.; Kamalakkannan, S.; Thangam, R.; Gunasekaran, P.; Krishnan, M.; Achiraman, S. Cytotoxic effect of green synthesized silver nanoparticles using melia azedarach against in vitro hela cell lines and lymphoma mice model. Process. Biochem. 2012, 47, 273-279. [CrossRef]

98. Poinern, G.E.J.; Chapman, P.; Shah, M.; Fawcett, D. Green biosynthesis of silver nanocubes using the leaf extracts from Eucalyptus macrocarpa. Nano Bull. 2013, 2, 130101.

99. Nayak, D.; Pradhan, S.; Ashe, S.; Rauta, P.R.; Nayak, B. Biologically synthesized silver nanoparticles from three diverse family of plant extracts and their anticancer activity against epidermoid A431 carcinoma. J. Colloid. Interface Sci. 2015, 457, 329-338. [CrossRef] [PubMed]

100. Logeswari, P.; Silambarasan, S.; Abraham, J. Synthesis of silver nanoparticles using plants extract and analysis of their antimicrobial property. J. Saudi Chem. Soc. 2015, 19, 311-317. [CrossRef]

101. Baharara, J.; Namvar, F.; Ramezani, T.; Mousavi, M.; Mohamad, R. Silver nanoparticles biosynthesized using achillea biebersteinii flower extract: Apoptosis induction in MCF-7 cells via caspase activation and regulation of Bax and Bcl-2 gene expression. Molecules 2015, 20, 2693-2706. [CrossRef] [PubMed]

102. Ramar, M.; Manikandan, B.; Marimuthu, P.N.; Raman, T.; Mahalingam, A.; Subramanian, P.; Karthick, S.; Munusamy, A. Synthesis of silver nanoparticles using Solanum trilobatum fruits extract and its antibacterial, cytotoxic activity against human breast cancer cell line MCF 7. Spectrochim. Acta Part A Mol. Biomol. Spectrosc. 2015, 140, 223-228. [CrossRef] [PubMed]

103. Ibrahim, M.M.H. Green synthesis and characterization of silver nanoparticles using banana peel extract and their antimicrobial activity against representative microorganisms. J. Radiat. Res. Appl. Sci. 2015, 8, $265-275$. [CrossRef]

104. Velayutham, K.; Ramanibai, R. Larvicidal activity of synthesized silver nanoparticles using isoamyl acetate identified in Annona squamosa leaves against Aedes aegypti and Culex quinquefasciatus. J. Basic Appl. Zool. 2016, 74, 16-22. [CrossRef]

105. Nalini, M.; Lena, M.; Sumathi, P.; Sundaravadivelan, C. Effect of phyto-synthesized silver nanoparticles on developmental stages of malaria vector, Anopheles stephensi and dengue vector, Aedes aegypti. Egypt. J. Basic Appl. Sci. 2017, 4, 212-218. [CrossRef]

106. Selvam, K.; Sudhakar, C.; Govarthanan, M.; Thiyagarajan, P.; Sengottaiyan, A.; Senthilkumar, B.; Selvankumar, T. Eco-friendly biosynthesis and characterization of silver nanoparticles using Tinospora cordifolia (Thunb.) miers and evaluate its antibacterial, antioxidant potential. J. Radiat. Res. Appl. Sci. 2017, 10, 6-12. [CrossRef]

107. Elumalai, D.; Hemavathi, M.; Deepaa, C.V.; Kaleena, P.K. Evaluation of phytosynthesised silver nanoparticles from leaf extracts of Leucas aspera and Hyptis suaveolens and their larvicidal activity against malaria, dengue and filariasis vectors. Parasite Epidemiology Control. 2017, 2, 15-26. [CrossRef] [PubMed]

108. Pourjavadi, A.; Soleyman, R. Novel silver nano-wedges for killing microorganisms. Mater. Res. Bull. 2011, 46, 1860-1865. [CrossRef] 
109. Ovais, M.; Khalil, A.T.; Raza, A.; Khan, M.A.; Ahmad, I.; Islam, N.U.; Saravanan, M.; Ubaid, M.F.; Ali, M.; Shinwari, Z.K. Green synthesis of silver nanoparticles via plant extracts: beginning a new era in cancer theranostics. Nanomedicine 2016, 11, 3157-3177. [CrossRef] [PubMed]

110. Ovais, M.; Nadhman, A.; Khalil, A.T.; Raza, A.; Khuda, F.; Sohail, M.F.; Sarwar, H.S.; Shahnaz, G.; Saravanan, M.; Shinwari, Z.K.; et al. Biosynthesized colloidal silver and gold nanoparticles as emerging leishmanicidal agents: an insight. Nanomedicine 2017, 12, 2807-2819. [CrossRef] [PubMed]

111. Narayanan, K.B.; Sakthivel, N. Green synthesis of biogenic metal nanoparticles by terrestrial and aquatic phototrophic and heterotrophic eukaryotes and biocompatible agents. Adv. Colloid Interface Sci. 2011, 169, 59-79. [CrossRef] [PubMed]

112. Kuppusamy, P.; Yusoff, M.M.; Maniam, G.P.; Govindan, N. Biosynthesis of metallic nanoparticles using plant derivatives and their new avenues in pharmacological applications-An updated report. Saudi Pharm. J. 2016, 24, 473-484. [CrossRef] [PubMed]

113. Singh, J.; Dutta, T.; Kim, K.-H.; Rawat, M.; Samddar, P.; Kumar, P. 'Green' synthesis of metals and their oxide nanoparticles: Applications for environmental remediation. J. Nanobiotechnology 2018, 16, 84. [CrossRef] [PubMed]

114. Rajeshkumar, S.; Bharath, L.V. Mechanism of plant-mediated synthesis of silver nanoparticles-A review on biomolecules involved, characterisation and antibacterialactivity. Chem. Biol. Interact. 2017, 273, $219-227$. [CrossRef]

115. Klaus, T.; Joerger, R.; Olsson, E.; Granqvist, C.-G. Silver-based crystalline nanoparticles, microbially fabricated. Proc. Natl. Acad. Sci. USA 1999, 96, 13611-13614. [CrossRef] [PubMed]

116. Joerger, R.; Klaus, T.; Granqvist, C.G. Biologically produced silver-carbon composite materials for optically functional thin-film coatings. Adv. Mater. 2000, 12, 407-409. [CrossRef]

117. Kowshik, M.; Ashtaputre, S.; Kharrazi, S.; Vogel, W.; Urban, J.; Kulkarni, S.K.; Paknikar, K.M. Extracellular synthesis of silver nanoparticles by a silver-tolerant yeast strain MKY3. Nanotechnology 2003, 14, 95-100. [CrossRef]

118. Ahmad, A.; Mukherjee, P.; Senapati, S.; Mandal, D.; Khan, M.; Kumar, R.; Sastry, M. Extracellular biosynthesis of silver nanoparticles using the fungus Fusarium oxysporum. Colloids Surfaces B Biointerfaces 2003, 28, 313-318. [CrossRef]

119. Durán, N.; Marcato, P.D.; Alves, O.L.; Souza, G.I.H.D.; Esposito, E. Mechanistic aspects of biosynthesis of silver nanoparticles by several Fusarium oxysporum strains. J. Nanobiotechnology 2005, 3, 8. [CrossRef]

120. Vigneshwaran, N.; Ashtaputre, N.; Varadarajan, P.; Nachane, R.; Paralikar, K.; Balasubramanya, R.; Nadanathangam, V. Biological synthesis of silver nanoparticles using the fungus Aspergillus flavus. Mater. Lett. 2007, 61, 1413-1418. [CrossRef]

121. Ingle, A.; Gade, A.; Pierrat, S.; Sonnichsen, C.; Rai, M. Mycosynthesis of silver nanoparticles using the fungus Fusarium acuminatum and its activity against some human pathogenic bacteria. Curr. Nanosci. 2008, 4, 141-144. [CrossRef]

122. Kalishwaralal, K.; Deepak, V.; Pandian, S.R.K.; Nellaiah, H.; Sangiliyandi, G. Extracellular biosynthesis of silver nanoparticles by the culture supernatant of Bacillus licheniformis. Mater. Lett. 2008, 62, 4411-4413. [CrossRef]

123. Kalimuthu, K.; Babu, R.S.; Venkataraman, D.; Bilal, M.; Gurunathan, S. Biosynthesis of silver nanocrystals by Bacillus licheniformis. Colloids Surf. B Biointerfaces 2008, 65, 150-153. [CrossRef]

124. Gurunathan, S.; Kalishwaralal, K.; Vaidyanathan, R.; Deepak, V.; Pandian, S.R.K.; Muniyandi, J.; Hariharan, N.; Eom, S.H. Biosynthesis, purifcation and characterization of silver nanoparticles using Escherichia coli. Colloid Surface B. 2009, 74, 328-335. [CrossRef]

125. Mokhtari, N.; Daneshpajouh, S.; Seyedbagheri, S.; Atashdehghan, R.; Abdi, K.; Sarkar, S.; Minaian, S.; Shahverdi, H.R.; Shahverdi, A.R.; Abdi, K. Biological synthesis of very small silver nanoparticles by culture supernatant of Klebsiella pneumonia: The effects of visible-light irradiation and the liquid mixing process. Mater. Res. Bull. 2009, 44, 1415-1421. [CrossRef]

126. Jaidev, L.R.; Narasimha, G. Fungal mediated biosynthesis of silver nanoparticles, characterization and antimicrobial activity. Colloids Surfaces B Biointerfaces 2010, 81, 430-433. [CrossRef] [PubMed]

127. Kalishwaralal, K.; Deepak, V.; Pandian, S.R.K.; Kottaisamy, M.; BarathManiKanth, S.; Kartikeyan, B.; Gurunathan, S. Biosynthesis of silver and gold nanoparticles using Brevibacterium casei. Colloids Surf. B Biointerfaces 2010, 77, 257-262. [CrossRef] [PubMed] 
128. Kumar, C.G.; Mamidyala, S.K. Extracellular synthesis of silver nanoparticles using culture supernatant of Pseudomonas aeruginosa. Colloids Surf. B Biointerfaces 2011, 84, 462-466. [CrossRef] [PubMed]

129. Banu, A.; Rathod, V.; Ranganath, E. Silver nanoparticle production by Rhizopus stolonifer and antibacterial activity against extended spectrum b-lactamase producing (ESBL) strains of Enterobacteriaceae. Mater. Res. Bull. 2011, 46, 1417-1423. [CrossRef]

130. Shivaji, S.; Madhu, S.; Singh, S. Extracellular synthesis of antibacterial silver nanoparticles using psychrophilic bacteria. Process. Biochem. 2011, 46, 1800-1807. [CrossRef]

131. Nayak, R.R.; Pradhan, N.; Behera, D.; Pradhan, K.M.; Mishra, S.; Sukla, L.B.; Mishra, B.K. Green synthesis of silver nanoparticle by Penicillium purpurogenum NPMF: the process and optimization. J. Nanoparticle Res. 2011, 13, 3129-3137. [CrossRef]

132. Kannan, N.; Mukunthan, K.; Balaji, S.; Seetharaman, B. A comparative study of morphology, reactivity and stability of synthesized silver nanoparticles using Bacillus subtilis and Catharanthus roseus (L.) G. Don. Colloids Surf. B Biointerfaces 2011, 86, 378-383. [CrossRef]

133. Wei, X.; Luo, M.; Li, W.; Yang, L.; Liang, X.; Xu, L.; Kong, P.; Liu, H. Synthesis of silver nanoparticles by solar irradiation of cell-free Bacillus amyloliquefaciens extracts and $\mathrm{AgNO}_{3}$. Bioresour. Technol. 2012, 103, 273-278. [CrossRef]

134. Sivalingam, P.; Antony, J.J.; Siva, D.; Achiraman, S.; Anbarasu, K. Mangrove streptomyces sp. BDUKAS10 as nanofactory for fabrication of bactericidal silver nanoparticles. Colloids Surf. B Biointerfaces 2012, 98, $12-17$. [CrossRef]

135. Samundeeswari, A.; Dhas, S.P.; Nirmala, J.; John, S.P.; Mukherjee, A.; Chandrasekaran, N. Biosynthesis of silver nanoparticles using actinobacterium Streptomyces albogriseolus and its antibacterial activity. Biotechnol. Appl. Biochem. 2012, 9, 503-507. [CrossRef] [PubMed]

136. Ghorbani, H.R. Biosynthesis of silver nanoparticles using Salmonella typhirium. J. Nanostructure Chem. 2013, 3, 29. [CrossRef]

137. Singh, D.; Rathod, V.; Ninganagouda, S.; Herimath, J.; Kulkarni, P. Biosynthesis of silver nanoparticle by endophytic fungi Pencillium sp. isolated from Curcuma longa (turmeric) and its antibacterial activity against pathogenic gram negative bacteria. J. Pharm. Res. 2013, 7, 448-453. [CrossRef]

138. Singh, R.; Wagh, P.; Wadhwani, S.; Gaidhani, S.; Kumbhar, A.; Bellare, J.; Chopade, B.A. Synthesis, optimization, and characterization of silver nanoparticles from Acinetobacter calcoaceticus and their enhanced antibacterial activity when combined with antibiotics. Int. J. Nanomed. 2013, 8, 4277-4290.

139. Neveen, M.K. Biogenic silver nanoparticles by Aspergillus terreus as a powerful nanoweapon against Aspergillus fumigatus. Afr. J. Microbiol. Res. 2013, 7, 5645-5651. [CrossRef]

140. Saravanan, M.; Jacob, V.; Arockiaraj, J.; Prakash, P. Extracellular Biosynthesis, Characterization and Antibacterial Activity of Silver Nanoparticles Synthesized by Bacillus subtilis (NCIM-2266). J. Bionanoscience 2014, 8, 21-27. [CrossRef]

141. Mohanta, Y.K.; Behera, S.K. Biosynthesis, characterization and antimicrobial activity of silver nanoparticles by Streptomyces sp. SS2. Bioprocess Biosyst. Eng. 2014, 37, 2263-2269. [CrossRef] [PubMed]

142. Singh, D.; Rathod, V.; Ninganagouda, S.; Hiremath, J.; Singh, A.K.; Mathew, J. Optimization and characterization of silver nanoparticle by endophytic fungi penicillium sp. isolated from curcuma longa (Turmeric) and application studies against MDR E. coli and S. aureus. Bioinorg. Chem. Appl. 2014, 2014, 1-8.

143. Das, V.L.; Thomas, R.; Varghese, R.T.; Soniya, E.V.; Mathew, J.; Radhakrishnan, E.K. Extracellular synthesis of silver nanoparticles by the Bacillus strain CS11 isolated from industrialized area. Biotech 2014, 4, 121-126.

144. Abdeen, S.; Geo, S.; Sukanya, A.; Praseetha, P.K.; Dhanya, R.P. Biosynthesis of silver nanoparticles from actinomycetes for therapeutic applications. Int. J. Nano Dimens. 2014, 5, 155-162.

145. Nanda, A.; Majeed, S. Enhanced antibacterial efficacy of biosynthesized AgNPs from penicillium glabrum (MTCC1985) pooled with different drugs. Int. J. PharmTech Res. 2014, 6, 217-223.

146. Zarina, A.; Nanda, A. Green approach for synthesis of silver nanoparticles from marine Streptomyces- MS 26 and their antibiotic efficacy. J. Pharm. Sci. Res. 2014, 6, 321-327.

147. Thomas, R.; Janardhanan, A.; Varghese, R.T.; Soniya, E.V.; Jyothis Mathew, J.; Radhakrishnan, E.K. Antibacterial properties of silver nanoparticles synthesized by marine Ochrobactrum sp. Braz. J. Microbiol. 2014, 45, 1221-1227. [CrossRef] [PubMed] 
148. Husseiny, S.M.; Salah, T.A.; Anter, H.A. Biosynthesis of size controlled silver nanoparticles by Fusarium oxysporum, their antibacterial and antitumor activities. Beni-Suef Univ. J. Basic Appl. Sci. 2015, 4, 225-231. [CrossRef]

149. Sarsar, V.; Selwal, M.K.; Selwal, K.K. Biofabrication, characterization and antibacterial efficacy of extracellular silver nanoparticles using novel fungal strain of Penicillium atramentosum KM. J. Saudi Chem. Soc. 2015, 19, 682-688. [CrossRef]

150. Du, J.; Yi, T.-H. Biosynthesis of silver nanoparticles by Variovorax guangxiensis THG-SQL3 and their antimicrobial potential. Mater. Lett. 2016, 178, 75-78. [CrossRef]

151. Singh, P.; Singh, H.; Kim, Y.J.; Mathiyalagan, R.; Wang, C.; Yang, D.C. Extracellular synthesis of silver and gold nanoparticles by Sporosarcina koreensis DC4 and their biological applications. Enzym. Microb. Technol. 2016, 86, 75-83. [CrossRef]

152. Majeed, S.; Bin Abdullah, M.S.; Nanda, A.; Ansari, M.T. In vitro study of the antibacterial and anticancer activities of silver nanoparticles synthesized from Penicillium brevicompactum (MTCC-1999). J. Taibah Univ. Sci. 2016, 10, 614-620. [CrossRef]

153. Jo, J.H.; Singh, P.; Kim, Y.J.; Wang, C.; Mathiyalagan, R.; Jin, C.-G.; Yang, D.C. Pseudomonas deceptionensis DC5-mediated synthesis of extracellular silver nanoparticles. Artif. Cells Nanomed. Biotechnol. 2016, 44, 1576-1581. [CrossRef]

154. Wang, C.; Kim, Y.J.; Singh, P. Green synthesis of silver nanoparticles by Bacillus methylotrophicus, and their antimicrobial activity. Artif. Cells Nanomed. Biotechnol. 2016, 44, 1127-1132.

155. Abd-Elnaby, H.M.; Abo-Elala, G.M.; Abdel-Raouf, U.M.; Hamed, M.M. Antibacterial and anticancer activity of extracellular synthesized silver nanoparticles from marine Streptomyces rochei MHM13. Egypt. J. Aquat. Res. 2016, 42, 301-312. [CrossRef]

156. Subbaiya, R.; Saravanan, M.; Priya, A.R.; Shankar, K.R.; Selvam, M.; Ovais, M.; Balajee, R.; Barabadi, H. Biomimetic synthesis of silver nanoparticles from Streptomyces atrovirens and their potential anticancer activity against human breast cancer cells. IET Nanobiotechnol. 2017, 11, 965-972. [CrossRef] [PubMed]

157. AbdelRahim, K.; Mahmoud, S.Y.; Ali, A.M.; Almaary, K.S.; Mustafa, A.E.; Husseiny, S.M. Extracellular biosynthesis of silver nanoparticles using Rhizopus stolonifer. Saudi J. Biol. Sci. 2017, 24, 208-216. [CrossRef] [PubMed]

158. Singh, H.; Du, J.; Yi, T.H. Biosynthesis of silver nanoparticles using Aeromonas sp. THG-FG1.2 and its antibacterial activity against pathogenic microbes. Artif. Cells Nanomed. Biotechnol. 2017, 45, 584-590. [CrossRef] [PubMed]

159. Saravanan, M.; Barik, S.K.; MubarakAli, D.; Prakash, P.; Pugazhendhi, A. Synthesis of silver nanoparticles from Bacillus brevis (NCIM 2533) and their antibacterial activity against pathogenic bacteria. Microb. Pathog. 2018, 116, 221-226. [CrossRef]

160. Saravanan, M.; Arokiyaraj, S.; Lakshmi, T.; Pugazhendhi, A. Synthesis of silver nanoparticles from Phenerochaete chrysosporium (MTCC-787) and their antibacterial activity against human pathogenic bacteria. Microb. Pathog. 2018, 117, 68-72. [CrossRef]

161. Buszewski, B.; Railean-Plugaru, V.; Pomastowski, P.; Rafińska, K.; Szultka-Mlynska, M.; Golinska, P.; Wypij, M.; Laskowski, D.; Dahm, H. Antimicrobial activity of biosilver nanoparticles produced by a novel Streptacidiphilus durhamensis strain. J. Microbiol. Immunol. Infect. 2018, 51, 45-54. [CrossRef]

162. Majeed, S.; Danish, M.; Zahrudin, A.H.B.; Dash, G.K. Biosynthesis and characterization of silver nanoparticles from fungal species and its antibacterial and anticancer effect. Karbala Int. J. Mod. Sci. 2018, 4, 86-92. [CrossRef]

163. Wypij, M.; Czarnecka, J.; Świecimska, M.; Dahm, H.; Rai, M.; Golinska, P. Synthesis, characterization and evaluation of antimicrobial and cytotoxic activities of biogenic silver nanoparticles synthesized from Streptomyces xinghaiensis OF1 strain. World J. Microbiol. Biotechnol. 2018, 34, 23. [CrossRef]

164. El-Baghdady, K.Z.; El-Shatoury, E.H.; Abdullah, O.M.; Khalil, M.M. Biogenic production of silver nanoparticles by Enterobacter cloacae Ism26. Turk. J. Boil. 2018, 42, 319-321. [CrossRef]

165. Sanjivkumar, M.; Vaishnavi, R.; Neelakannan, M.; Kannan, D.; Silambarasan, T.; Immanuel, G. Investigation on characterization and biomedical properties of silver nanoparticles synthesized by an actinobacterium Streptomyces olivaceus (MSU3). Biocatal. Agric. Biotechnol. 2019, 17, 151-159. [CrossRef] 
166. Zhang, Z.; Li, S.; Gu, X.; Li, J.; Lin, X. Biosynthesis, characterization and antibacterial activity of silver nanoparticles by the Arctic anti-oxidative bacterium Paracoccus sp. Arc7-R13. Artif. Cells Nanomed. Biotechnol. 2019, 47, 1488-1495. [CrossRef] [PubMed]

167. Bhainsa, K.C.; D'Souza, S.F. Extracellular biosynthesis of silver nanoparticles using the fungus Aspergillus fumigates. Colloids Surf. B 2006, 47, 160-164. [CrossRef] [PubMed]

168. Saravanan, M.; Nanda, A. Extracellular synthesis of silver bionanoparticles from Aspergillus clavatus and its antimicrobial activity against MRSA and MRSE. Colloids Surf. B Biointerfaces 2010, 77, 214-218. [CrossRef] [PubMed]

169. Saravanan, M.; Vemu, A.K.; Barik, S.K. Rapid biosynthesis of silver nanoparticles from Bacillus megaterium (NCIM 2326) and their antibacterial activity on multi drug resistant clinical pathogens. Colloids Surfaces B Biointerfaces 2011, 88, 325-331. [CrossRef] [PubMed]

170. Jain, N.; Bhargava, A.; Majumdar, S.; Tarafdar, J.C.; Panwar, J. Extracellular biosynthesis and characterization of silver nanoparticles using aspergillus flavusNJP08: A mechanism perspective. Nanoscale 2011, 3, 635-641. [CrossRef] [PubMed]

171. Jeevan, P.; Ramya, K.; Rena, A.E. Extracellular biosynthesis of silver nanoparticles by culture supernatant of pseudomonas aeruginosa. Indian J. Biotechnol. 2012, 11, 72-76.

172. Seshadri, S.; Prakash, A.; Kowshik, M. Biosynthesis of silver nanoparticles by marine bacterium, Idiomarina sp. PR58-8. Bull. Mater. Sci. 2012, 35, 1201-1205. [CrossRef]

173. Manikprabhu, D.; Lingappa, K. Antibacterial activity of silver nanoparticles against methicillin-resistant Staphylococcus aureus synthesized using model Streptomyces sp. pigment by photo-irradiation method. J. Pharm. Res. 2013, 6, 255-260. [CrossRef]

174. Chauhan, R.; Kumar, A.; Abraham, J. A biological approach to the synthesis of silver nanoparticles with Streptomyces sp. JAR1 and its antimicrobial activity. Sci. Pharm. 2013, 81, 607-621. [CrossRef]

175. Chandrakanth, K.R.; Ashajyothi, C.; Oli, A.K.; Prabhurajeshwar, C. Potential bactericidal effect of silver nanoparticles synthesized from Enterococcus species. Orient J. Chem. 2014, 30, 1253-1262.

176. Saminathan, K. Biosynthesis of silver nanoparticles using soil actinomycetes Streptomyces sp. Int. J. Curr. Microbiol. Appl. Sci. 2015, 4, 1073-1083.

177. Shaker, M.A.; Shaaban, M.I. Synthesis of silver nanoparticles with antimicrobial and anti-adherence activities against multidrug-resistant isolates from Acinetobacter baumannii. J. Taibah Univ. Med. Sci. 2017, 12, $291-297$. [CrossRef] [PubMed]

178. Singh, H.; Du, J.; Singh, P.; Yi, T.H. Extracellular synthesis of silver nanoparticles by Pseudomonas sp. THG-LS1.4 and their antimicrobial application. J. Pharm. Anal. 2018, 8, 258-264. [CrossRef] [PubMed]

179. Priyadarshini, S.; Gopinath, V.; Priyadharsshini, N.M.; MubarakAli, D.; Velusamy, P. Synthesis of anisotropic silver nanoparticles using novel strain, Bacillus flexus and its biomedical application. Colloids Surf. B Biointerfaces 2013, 102, 232-237. [CrossRef] [PubMed]

180. Hosseini-Abari, A.; Emtiazi, G.; Lee, S.-H.; Kim, B.-G.; Kim, J.-H. Biosynthesis of Silver Nanoparticles by Bacillus stratosphericus Spores and the Role of Dipicolinic Acid in This Process. Appl. Biochem. Biotechnol. 2014, 174, 270-282. [CrossRef] [PubMed]

181. Basavaraja, S.; Balaji, S.; Lagashetty, A.; Rajasab, A.; Venkataraman, A. Extracellular biosynthesis of silver nanoparticles using the fungus Fusarium semitectum. Mater. Res. Bull. 2008, 43, 1164-1170. [CrossRef]

182. Verma, V.C.; Kharwar, R.N.; Gange, A.C. Biosynthesis of antimicrobial silver nanoparticles by the endophytic fungusAspergillus clavatus. Nanomedicine 2010, 5, 33-40. [CrossRef] [PubMed]

183. Mishra, A.; Sardar, M. Alpha-amylase mediated synthesis of silver nanoparticles. Sci. Adv. Mater. 2012, 4, 143-146. [CrossRef]

184. Mohamedin, A.; El-Naggar, N.E.-A.; Hamza, S.S.; Sherief, A. Green synthesis, characterization and antimicrobial activities of silver nanoparticles by streptomyces viridodiastaticus SSHH-1 as a living nanofactory: Statistical optimization of process variables. Curr. Nanosci. 2015, 11, 640-654. [CrossRef]

185. Husain, S.; Sardar, M.; Fatma, T. Screening of cyanobacterial extracts for synthesis of silver nanoparticles. World J. Microbiol. Biotechnol. 2015, 31, 1279-1283. [CrossRef] [PubMed]

186. Kim, Y.J.; Singh, P.; Mathiyalagan, R.; Wang, C.; Yang, D.C. Biosynthesis of anisotropic silver nanoparticles by bhargavaea indica and their synergistic effect with antibiotics against pathogenic microorganisms. J. Nanomater. 2015, 2015, 1-10. 
187. Xu, J.; Cheng, G.-A.; Zheng, R.-T. Controllable synthesis of highly ordered Ag nanorod arrays by chemical deposition method. Appl. Surf. Sci. 2010, 256, 5006-5010. [CrossRef]

188. Murphy, C.; Jana, N. Controlling the Aspect Ratio of Inorganic Nanorods and Nanowires. Adv. Mater. 2002, 14, 80-82. [CrossRef]

189. Wiley, B.J.; Chen, Y.; McLellan, J.M.; Xiong, Y.; Li, Z.-Y.; Ginger, D.; Xia, Y. Synthesis and Optical Properties of Silver Nanobars and Nanorice. Nano Lett. 2007, 7, 1032-1036. [CrossRef] [PubMed]

190. Wird, A.G.; Courts, A. The Science and Technology of Gelatin; Academic Press: New York, NY, USA, 1977.

191. Ramachadran, G.N. Treatise on collagen. Science 1969, 164, 172.

192. Boedtker, H.; Doty, P. A Study of Gelatin Molecules, Aggregates and Gels. J. Phys. Chem. 1954, 58, 968-983. [CrossRef]

193. James, T.H.; Mees, C.E. The Theory of the Photographic Process; Macmillan: New York, NY, USA, 1972.

194. James, T.H. The Theory of the Photographic Process; Macmillan: New York, NY, USA, 1977.

195. Mikhailov, O.V. Synthesis of 3d-element metalmacrocyclic chelates into polypeptide biopolymer medium and their molecular structures. Inorganica Chim. Acta 2013, 394, 664-684. [CrossRef]

196. Mikhailov, O.V. Sol-gel technology and template synthesis in thin gelatin films. J. Sol-Gel Sci. Technol. 2014, 72, 314-327. [CrossRef]

197. Mikhailov, O.V. Molecular structure design and soft template synthesis of aza-, oxaaza- and thiaazamacrocyclic metal chelates in the gelatin matrix. Arab. J. Chem. 2017, 10, 47-67. [CrossRef]

198. Mikhailov, O.V. Electron microscopy of elemental silver produced by its reprecipitation in glass-like biopolymer film. Glas. Phys. Chem. 2017, 43, 471-474. [CrossRef]

199. Mikhailov, O.V. Enzyme-assisted matrix isolation of novel dithiooxamide complexes of nickel(II). Indian J. Chem. A 1991, 30, 252-254.

200. Mikhailov, O. Synthesis of Ag nanoparticles under a contact of water solution with silver(I)chloride biopolymer matrix. J. Mol. Liq. 2019, 291. [CrossRef]

201. Mikhailov, O.V.; Kondakov, A.V.; Krikunenko, R.I. Image Intensification in Silver Halide Photographic Materials for Detection of High-Energy Radiation by Reprecipitation of Elemental Silver. High Energy Chem. 2005, 39, 324-329. [CrossRef]

202. Mikhailov, O.V. Self-assembly of molecules of metal macrocyclic compounds in nanoreactors on the basis of biopolymer-immobilized matrix systems. Nanotechnologies Russ. 2010, 5, 18-34. [CrossRef]

203. Mikhailov, O.V. Molecular nanotechnologies of gelatin-immobilization using macrocyclic metal chelates. Nano Rev. 2014, 5, 14767. [CrossRef] [PubMed]

204. Lu, R.; Yang, D.; Cui, D.; Wang, Z.; Guo, L. Egg white-mediated green synthesis of silver nanoparticles with excellent biocompatibility and enhanced radiation effects on cancer cells. Int. J. Nanomed. 2012, 7, 2101-2107. [CrossRef] [PubMed]

205. Eby, D.M.; Schaeublin, N.M.; Farrington, K.E.; Hussain, S.M.; Johnson, G.R. Lysozyme catalyzes the formation of antimicrobial silver nanoparticles. ACS Nano 2009, 3, 984-994. [CrossRef]

206. Singh, A.V.; Bandgar, B.M.; Kasture, M.; Prasad, B.L.V.; Sastry, M. Synthesis of gold, silver and their alloy nanoparticles using bovine serum albumin as foaming and stabilizing agent. J. Mater. Chem. 2005, 15, 5115. [CrossRef]

207. Dickerson, M.B.; Sandhage, K.H.; Naik, R.R. Protein- and peptide-directed synthesis of inorganic materials. Chem. Revs. 2008, 108, 4935-4978. [CrossRef]

208. Sogias, I.A.; Williams, A.C.; Khutoryanskiy, V.V. Why is chitosan mucoadhesive? Biomacromolecules 2008, 9, 1837-1842. [CrossRef] [PubMed]

209. Casettari, L.; Illum, L. Chitosan in nasal delivery systems for therapeutic drugs. J. Control. Release 2014, 190, 189-200. [CrossRef] [PubMed]

210. Qu, X.; Khutoryanskiy, V.V.; Stewart, A.; Rahman, S.; Papahadjopoulos-Sternberg, B.; Dufes, C.; McCarthy, D.; Wilson, C.G.; Lyons, R.; Carter, K.C.; et al. Carbohydrate-Based Micelle Clusters Which Enhance Hydrophobic Drug Bioavailability by Up to 1 Order of Magnitude. Biomacromolecules 2006, 7, 3452-3459. [CrossRef] [PubMed]

211. Koland, M.; Vijayanarayana, K.; Charyulu, R.N.; Prabhu, P. In vitro and in vivo evaluation of chitosan buccal films of ondansetron hydrochloride. Int. J. Pharm. Investig. 2011, 1, 164-171. [CrossRef] [PubMed] 
212. Apryatina, K.V.; Mochalova, A.E.; Gracheva, T.A.; Kuz'micheva, T.A.; Smirnova, L.A.; Smirnova, O.N. Vliyanie molekularnoi massy khitozana na razmernye kharakteristiki nanochastitz serebra. Vysok. Soedin. B. 2015, 57, 154-158.

213. Apryatina, K.V.; Mochalova, A.E.; Gracheva, T.A.; Kuz'Micheva, T.A.; Smirnova, O.N.; Smirnova, L. Influence of the molecular mass of chitosan on the dimensional characteristics of silver nanoparticles. Polym. Sci. Ser. B 2015, 57, 145-149. [CrossRef]

214. Uryupina, O.Y.; Urodkova, E.K.; Zhavoronok, E.S.; Vysotskii, V.V.; Senchikhin, I.N. Synthesis of monodisperse silver nanoparticles in chitosan solutions. Colloid J. 2019, 81, 194-198. [CrossRef]

215. Shirokova, L.N.; Alexandrova, V.A. Radiatsionno-khimicheskii sintez nanochastits serebra v karboximetilkhitine. Dokl. Akad. Nauk. 2015, 464, 440-443.

216. Shirokova, L.N.; Alexandrova, V.A. Radiation-chemical synthesis of silver nanoparticles in carboxymethyl chitin. Dokl. Phys. Chem. 2015, 464, 234-237. [CrossRef]

217. Laudenslager, M.J.; Schiffman, J.D.; Schauer, C.L. Carboxymethyl Chitosan as a Matrix Material for Platinum, Gold, and Silver Nanoparticles. Biomacromolecules 2008, 9, 2682-2685. [CrossRef]

218. Wei, D.; Qian, W. Facile synthesis of Ag and Au nanoparticles utilizing chitosan as a mediator agent. Colloids Surf. B Biointerfaces 2008, 62, 136-142. [CrossRef]

219. Wang, B.; Zhuang, X.; Deng, W.; Cheng, B. Microwave-assisted synthesis of silver nanoparticles in alkalic carboxymethyl chitosan solution. Engineering 2010, 2, 387-390. [CrossRef]

220. Biswal, J.; Ramnani, S.P.; Shirolikar, S.; Sabharwal, S. Synthesis of guar-gum-stabilized nanosized silver clusters with $\gamma$ radiation. J. Appl. Polym. Sci. 2009, 114, 2348-2355. [CrossRef]

221. Ameen, K.B.; Rajasekar, K.; Rajasekharan, T. Silver nanoparticles in mesoporous aerogel exhibiting selective catalytic oxidation of benzene in $\mathrm{CO}_{2}$ free air. Catal. Lett. 2007, 119, 289-295. [CrossRef]

222. Jiang, Z.-J.; Liu, C.-Y.; Sun, L.-W. Catalytic properties of silver nanoparticles supported on silica spheres. J. Phys. Chem. B 2005, 109, 1730-1735. [CrossRef] [PubMed]

223. Wu, M.; Lakowicz, J.R.; Geddes, C.D. Enhanced lanthanide luminescence using silver nanostructures: Opportunities for a new class of probes with exceptional spectral characteristics. J. Fluoresc. 2005, 15, 53-59. [CrossRef] [PubMed]

224. Lakowicz, J.R.; Maliwal, B.P.; Malicka, J.; Gryczynski, Z.; Gryczynski, I. Effects of silver island films on the luminescent intensity and decay times of lanthanide chelates. J. Fluoresc. 2002, 12, 431-437. [CrossRef]

225. Lee, I.-Y.S.; Suzuki, H.; Ito, K.; Yasuda, Y. Surface-enhanced fluorescence and reverse saturable absorption on silver nanoparticles. J. Phys. Chem. B 2004, 108, 19368-19372. [CrossRef]

226. Aslan, K.; Holley, P.; Geddes, C.D. Metal-enhanced fluorescence from silver nanoparticle-deposited polycarbonate substrates. J. Mater. Chem. 2006, 16, 2846. [CrossRef]

227. Chowdhury, M.H.; Aslan, K.; Malyn, S.N.; Lakowicz, J.R.; Geddes, C.D. Metal-enhanced chemiluminescence. J. Fluorescence 2006, 16, 295-299. [CrossRef]

228. Aslan, K.; Leonenko, Z.; Lakowicz, J.R.; Geddes, C.D. Annealed silver-island films for applications in metal-enhanced fluorescence: interpretation in terms of radiating plasmons. J. Fluoresc. 2005, 15, 643-654. [CrossRef] [PubMed]

229. Lipovskii, A.; Kuittinen, M.; Karvinen, P.; Leinonen, K.; Melehin, V.G.; Zhurikhina, V.V.; Svirko, Y.P. Electric field imprinting of sub-micron patterns in glass-metal nanocomposites. Nanotechnol. 2008, 19, 415304. [CrossRef] [PubMed]

230. Hashemifard, N.; Mohsenifar, A.; Ranjbar, B.; Allameh, A.; Lotfi, A.; Etemadikia, B. Fabrication and kinetic studies of a novel silver nanoparticles-glucose oxidase bioconjugate. Anal. Chim. Acta 2010, 675, 181-184. [CrossRef]

231. Xie, T.; Wang, A.; Huang, L.; Li, H.; Chen, Z.; Wang, Q.; Yin, X. Recent advance in the support and technology used in enzyme immobilization. African J. Biotechnol. 2009, 8, 4724-4733.

232. Raghava, S.; Singh, P.K.; Rao, A.R.; Dutta, V.; Gupta, M.N. Nanoparticles of unmodified titanium dioxide facilitate protein refolding. J. Mater. Chem. 2009, 19, 2830-2834. [CrossRef]

233. Horcajada, P.; Serre, C.; Maurin, G.; Ramsahye, N.A.; Balas, F.; Vallet-Regí, M.; Sebban, M.; Taulelle, F.; Ferey, G. Flexible porous metal-organic frameworks for a controlled drug delivery. J. Am. Chem. Soc. 2008, 130, 6774-6780. [CrossRef] [PubMed] 
234. Ahn, B.Y.; Duoss, E.B.; Motala, M.J.; Guo, X.; Park, S.-I.; Xiong, Y.; Yoon, J.; Nuzzo, R.G.; Rogers, J.A.; Lewis, J.A. Omnidirectional Printing of Flexible, Stretchable, and Spanning Silver Microelectrodes. Science 2009, 323, 1590-1593. [CrossRef] [PubMed]

235. Franci, G.; Falanga, A.; Galdiero, S.; Palomba, L.; Rai, M.; Morelli, G.; Galdiero, M. Silver Nanoparticles as potential antibacterial agents. Molecules 2015, 20, 8856-8874. [CrossRef]

236. Singh, P.; Kim, Y.J.; Singh, H.; Wang, C.; Hwang, K.H.; Farh, M.E.-A.; Yang, D.-C. Biosynthesis, characterization, and antimicrobial applications of silver nanoparticles. Int. J. Nanomed. 2015, 10, 2567-2577.

237. Abdelghany, T.M.; Al-Rajhi, A.M.H.; Al Abboud, M.A.; Alawlaqi, M.M.; Magdah, A.G.; Helmy, E.A.M.; Mabrouk, A.S. Recent advances in green synthesis of silver nanoparticles and their applications: About future directions. a review. BioNanoSci. 2018, 8, 5-16. [CrossRef]

238. Verma, P.; Maheshwari, S.K. Applications of silver nanoparticles in diverse sectors. Int. J. Nano Dimens. 2019, $10,18-36$.

239. Klasen, H.J. A historical review of the use of silver in the treatment of burns. Burns 2000, 26, 117-130. [CrossRef]

240. Pal, S.; Tak, Y.K.; Song, J.M. Does the Antibacterial Activity of Silver Nanoparticles Depend on the Shape of the Nanoparticle? A Study of the Gram-Negative Bacterium Escherichia coli. Appl. Environ. Microbiol. 2007, 73, 1712-1720. [CrossRef] [PubMed]

241. Kairemo, K.; Erba, P.; Bergström, K.; Pauwels, E.K.J. Nanoparticles in cancer. Curr. Radiopharm. 2010, 1, 30-36.

242. Agasti, S.S.; Chompoosor, A.; You, C.-C.; Ghosh, P.; Kim, C.K.; Rotello, V.M. Photoregulated release of caged anticancer drugs from gold nanoparticles. J. Am. Chem. Soc. 2009, 131, 5728-5729. [CrossRef] [PubMed]

243. Hong, R.; Han, G.; Fernández, J.M.; Kim, B.-J.; Forbes, N.S.; Rotello, V.M. Glutathione-mediated delivery and release using monolayer protected nanoparticle carriers. J. Am. Chem. Soc. 2006, 128, 1078-1079. [CrossRef] [PubMed]

244. Fodale, V.; Pierobon, M.; Liotta, L.; Petricoin, E. Mechanism of cell adaptation: when and how do cancer cells develop chemoresistance? Cancer J. 2011, 17, 89-95. [CrossRef]

245. Shahverdi, A.R.; Fakhimi, A.; Shahverdi, H.R.; Minaian, S. Synthesis and effect of silver nanoparticles on the antibacterial activity of different antibiotics against Staphylococcus aureus and escherichia coli. Nanomed. Nanotechnol. Boil. Med. 2007, 3, 168-171. [CrossRef]

246. Cushen, M.; Kerry, J.; Morris, M.; Cruz-Romero, M.; Cummins, E. Nanotechnologies in the food industry-Recent developments, risks and regulation. Trends Food Sci. Technol. 2012, 24, 30-46. [CrossRef]

247. Huang, Y.; Chen, S.; Bing, X.; Gao, C.; Wang, T.; Yuan, B. Nanosilver Migrated into Food-Simulating Solutions from Commercially Available Food Fresh Containers. Packag. Technol. Sci. 2011, 24, 291-297. [CrossRef]

248. Besinis, A.; De Peralta, T.; Handy, R.D. The antibacterial effects of silver, titanium dioxide and silica dioxide nanoparticles compared to the dental disinfectant chlorhexidine on Streptococcus mutans using a suite of bioassays. Nanotoxicology 2014, 8, 1-16. [CrossRef] [PubMed]

249. Parashar, U.K.; Kumar, V.; Bera, T.; Saxena, P.S.; Nath, G.; Srivastava, S.K.; Giri, R.; Srivastava, A. Study of mechanism of enhanced antibacterial activity by green synthesis of silver nanoparticles. Nanotechnol. 2011, 22, 415104. [CrossRef] [PubMed]

250. Agnihotri, S.; Mukherji, S.; Mukherji, S. Immobilized silver nanoparticles enhance contact killing and show highest efficacy: Elucidation of the mechanism of bactericidal action of silver. Nanoscale 2013, 5, 7328. [CrossRef] [PubMed]

251. De Moraes, A.C.M.; Lima, B.A.; De Faria, A.F.; Brocchi, M.; Alves, O.L. Graphene oxide-silver nanocomposite as a promising biocidal agent against methicillin-resistant Staphylococcus aureus. Int. J. Nanomed. 2015, 10, 6847-6861. [CrossRef] [PubMed]

252. Esteban-Tejeda, L.; Malpartida, F.; Esteban-Cubillo, A.; Pecharromán, C.; Moya, J.S. The antibacterial and antifungal activity of a soda-lime glass containing silver nanoparticles. Nanotechnology 2009, 20, 085103. [CrossRef] [PubMed]

253. Chen, Q.C.; Jiang, H.J.; Ye, H.L.; Li, J.R.; Huang, J.Y. Preparation, antibacterial, and antioxidant activities of silver/chitosan composites. J. Carbohydr. Chem. 2014, 33, 298-312. [CrossRef]

254. Shao, W.; Liu, X.; Min, H.; Dong, G.; Feng, Q.; Zuo, S. Preparation, Characterization, and Antibacterial Activity of Silver Nanoparticle-Decorated Graphene Oxide Nanocomposite. ACS Appl. Mater. Interfaces 2015, 7, 6966-6973. [CrossRef] 
255. Khurana, C.; Vala, A.K.; Andhariya, N.; Pandey, O.P.; Chudasama, B. Antibacterial activity of silver: The role of hydrodynamic particle size at nanoscale. J. Biomed. Mater. Res. A 2014, 102, 3361-3368. [CrossRef]

256. Kittler, S.; Greulich, C.; Diendorf, J.; Koller, M.; Epple, M. Toxicity of Silver Nanoparticles Increases during Storage Because of Slow Dissolution under Release of Silver Ions. Chem. Mater. 2010, 22, 4548-4554. [CrossRef]

257. Ahamed, M.; Alsalhi, M.S.; Siddiqui, M.K. Silver nanoparticle applications and human health. Clin. Chim. Acta 2010, 411, 1841-1848. [CrossRef]

258. Hirai, T.; Yoshioka, Y.; Ichihashi, K.; Mori, T.; Nishijima, N.; Handa, T.; Takahashi, H.; Tsunoda, S.; Higashisaka, K.; Tsutsumi, Y. Silver nanoparticles induce silver nanoparticle-specific allergic responses (HYP6P.274). J. Immunol. 2014, 192, 118.19. Available online: https://www.jimmunol.org/content/192/1_ Supplement/118.19.short (accessed on 31 August 2019).

259. Laban, G.; Nies, L.F.; Turco, R.F.; Bickham, J.W.; Sepúlveda, M.S. The effects of silver nanoparticles on fathead minnow (Pimephales promelas) embryos. Ecotoxicology 2009, 19, 185-195. [CrossRef] [PubMed]

260. Asharani, P.V.; Wu, Y.L.; Gong, Z.; Valiyaveettil, S. Toxicity of silver nanoparticles in zebrafish models. Nanotechnology 2008, 19, 255102. [CrossRef] [PubMed]

261. AshRani, P.V.; Low Kah Mun, G.; Hande, M.P.; Valiyaveettil, S. Cytotoxicity and genotoxicity of silver nanoparticles in human cells. ACS Nano 2009, 3, 279-290. [CrossRef] [PubMed]

262. Thiago, V.-B.; Rona, M.-G.; Katarzyna, W.; Adelina, R.-W.; Jonathan, R.B.; Helmut, E.; Frank, K. Insights into the cellular response triggered by silver nanoparticles using quantitative proteomics. ACS Nano 2014, 8, 2161-2175.

(C) 2019 by the authors. Licensee MDPI, Basel, Switzerland. This article is an open access article distributed under the terms and conditions of the Creative Commons Attribution (CC BY) license (http://creativecommons.org/licenses/by/4.0/). 